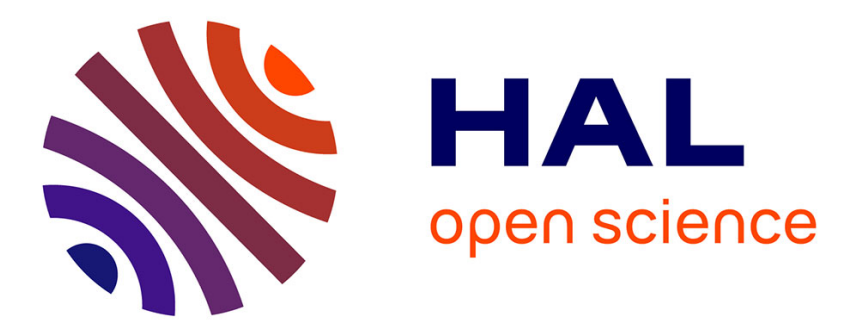

\title{
Pluriannual comparisons of satellite-based rainfall products over the Sahelian belt for seasonal vegetation modeling
}

Charles Pierre, G. Bergametti, B. Marticoréna, Éric Mougin, T. Lebel, A. Ali

\section{- To cite this version:}

Charles Pierre, G. Bergametti, B. Marticoréna, Éric Mougin, T. Lebel, et al.. Pluriannual comparisons of satellite-based rainfall products over the Sahelian belt for seasonal vegetation modeling. Journal of Geophysical Research, 2011, 116, pp.D18201. 10.1029/2011JD016115 . insu-00649225

\section{HAL Id: insu-00649225}

https://hal-insu.archives-ouvertes.fr/insu-00649225

Submitted on 12 Mar 2021

HAL is a multi-disciplinary open access archive for the deposit and dissemination of scientific research documents, whether they are published or not. The documents may come from teaching and research institutions in France or abroad, or from public or private research centers.
L'archive ouverte pluridisciplinaire HAL, est destinée au dépôt et à la diffusion de documents scientifiques de niveau recherche, publiés ou non, émanant des établissements d'enseignement et de recherche français ou étrangers, des laboratoires publics ou privés. 


\title{
Pluriannual comparisons of satellite-based rainfall products over the Sahelian belt for seasonal vegetation modeling
}

\author{
Caroline Pierre, ${ }^{1}$ Gilles Bergametti, ${ }^{1}$ Béatrice Marticorena, ${ }^{1}$ Eric Mougin, ${ }^{2}$ Thierry Lebel, ${ }^{3}$ \\ and Abdou Ali ${ }^{3,4}$ \\ Received 15 April 2011; revised 28 June 2011; accepted 11 July 2011; published 17 September 2011.
}

[1] The Sahel corresponds to the transition from the dry arid desert to wet savannahs, where vegetation exhibits a well-marked seasonal cycle in response to the West African Monsoon. Precipitation data sets with high spatial and temporal resolutions are therefore relevant to investigate the dynamics of the Sahelian vegetation. Three satellite-based precipitation products (TRMM3B42, RFE2.0, and CMORPH) are compared and tested against kriged rain gauge measurements. The objective is to evaluate their capability to retrieve the main precipitation characteristics during the rainy season. Comparisons are performed over a 4 year period (2004-2007) at spatial resolutions of $0.25^{\circ} \times 0.25^{\circ}$ or $0.5^{\circ} \times 0.5^{\circ}$ by looking at sensitive criteria for vegetation: spatial distribution of the rainfall field, precipitation frequency, dry spell distribution, and precipitation amounts. Intercomparisons between satellite data sets are conducted over the Sahelian belt $\left(10^{\circ} \mathrm{N}-20^{\circ} \mathrm{N} ; 20^{\circ} \mathrm{W}-35^{\circ} \mathrm{E}\right)$ at a 1-10 day time scale, while comparisons with 10 day kriged rain gauge measurements are performed over a smaller area $\left(10^{\circ} \mathrm{N}-17.5^{\circ} \mathrm{N} ; 17.5^{\circ} \mathrm{W}-2.5^{\circ} \mathrm{E}\right)$. The precipitation spatial distributions are in good agreement between satellite products and with the kriged data. Considering the daily frequency, the satellite products show a high agreement between them $(\sim 80 \%)$. The TRMM3B42 product exhibits the lowest number of rainy days, and RFE2.0 exhibits the highest. The CMORPH product overestimates rainfall amounts, while TRMM3B42 and RFE2.0 are both in good agreement with the kriged data. The impacts of these distinctive behaviors on simulated vegetation are investigated by comparisons with MODIS LAI, considering vegetation dynamics and amounts. The studied criteria of precipitation fields appear as a critical issue for Sahelian vegetation modeling.

Citation: Pierre, C., G. Bergametti, B. Marticorena, E. Mougin, T. Lebel, and A. Ali (2011), Pluriannual comparisons of satellite-based rainfall products over the Sahelian belt for seasonal vegetation modeling, J. Geophys. Res., 116, D18201, doi:10.1029/2011JD016115.

\section{Introduction}

[2] The Sahel is usually defined as the region of Africa limited by the isohyets $100 \mathrm{~mm}$ (northern border) and $600 \mathrm{~mm}$ (southern border). This region extends over 400 to $600 \mathrm{~km}$ to the south of the Sahara desert, depending on the year [Le Houérou, 1989]. The latitudinal gradient of precipitation is thus extremely strong, with about $1 \mathrm{~mm} \mathrm{~km}^{-1}$ [Lebel et al., 2003]. The rainy season, associated to the West African Monsoon (WAM) regime, lasts from May to October at most in Sahel, with a maximum in August [Lebel and Ali, 2009].

\footnotetext{
${ }^{1}$ Laboratoire Interuniversitaire des Systèmes Atmosphériques, Universités Paris-Est Créteil and Paris-Diderot, UMR CNRS 7583, Creteil, France.

${ }^{2}$ Géosciences Environnement Toulouse, UMR 5563 (CNRS-IRDUPS), Observatoire Midi-Pyrénées, Toulouse, France.

${ }^{3}$ Laboratoire d'Etude des Transferts en Hydrologie et Environnement, UMR 5564 (CNRS-UJF-IRD-INPG), Grenoble, France.

${ }^{4}$ Centre Régional de Formation et d'Application en Agrométéorologie, Hydrologie et Météorologie, Niamey, Niger.

Copyright 2011 by the American Geophysical Union. 0148-0227/11/2011JD016115
}

The annual rainfall amount is provided by a limited number of organized convective systems occurring during the rainy season [Mathon et al., 2002].

[3] In response to this monomodal distribution of precipitation, the Sahelian vegetation is mainly composed of annual plants, scattered shrubs, and low trees, and it exhibits a well-marked seasonal cycle [Le Houérou, 1989]. Annuals germinate after the first rains, in June or July, and unless the plants wilted before maturity because of lack of rain, plant senescence immediately follows the fructification, largely determined by plant sensitivity to the photoperiod and matching approximately with the end of the rainy season. The herbaceous growing season is followed by a long dry season of about 8-10 months during which there is no herbaceous growth. During this period, standing herb cover decreases slowly during the first part of the dry season. This decrease accelerates from March on as the air temperature and humidity build on. This strong temporal dynamics associated with wide spatial heterogeneity raises a challenge for modeling vegetation dynamics over the Sahel belt. Furthermore, reliable rainfall maps are critical to the 
investigation of scientific issues such as dust emission in semiarid regions [e.g., MacKinnon et al., 2004; Mulitza et al., 2010] or hydrological regimes [e.g., Hossain and Huffman, 2008].

[4] In the semiarid region of Sahel, the most limiting factor for plant growth is the water content in the rooting zone [e.g., Rambal and Cornet, 1982; Mougin et al., 2009a]. In consequence, the timing of plant growth depends on the rainfall volume and distribution during the rainy season [Rambal and Cornet, 1982]. Indeed, the extent of the seasonal growth of annual herbaceous not only depends on the annual precipitation amounts, but also on their distribution over time and space [Hiernaux and Le Houérou, 2006]. Accordingly, precipitation data sets with high spatial and temporal resolutions are requested as main inputs in vegetation dynamical models. As an example, the Sahelian Transpiration Evaporation and Productivity (STEP) model [Mougin et al., 1995] requires daily rainfall inputs.

[5] Since the Sahel droughts in the 1970s to 1980 s, the mechanisms controlling the monsoon system have been largely studied [see e.g., Le Barbé et al., 2002; Ali and Lebel, 2008]. Direct measurements of rainfall using gauges are performed in a network of meteorological stations, while indirect assessments of rainfall are increasingly carried out using censors onboard satellites. However, the gauge network is too sparse in many regions of the Sahel to allow precise estimates of the spatial pattern of precipitation at local (away from the gauge) to regional scales. Nowadays, the temporal distribution of precipitation can be investigated at regional to continental scales using a new generation of precipitation products combining infrared (IR) and microwave (MW) measurements [Xie and Arkin, 1996; Hsu et al., 1997; Sorooshian et al., 2000; Huffman et al., 2001; Joyce et al., 2004; Huffman et al., 2007; Bergès et al., 2010]. These products benefit from the good sampling rate of IR measurements from geostationary satellites and from the relatively high confidence level in rainfall estimates provided by MW sensors onboard various polar satellites. Many studies have already investigated the quality of these high spatial-and-temporal resolution precipitation products [Negri et al., 1995; Laurent et al., 1998; Nicholson et al., 2003; Ali et al., 2005b; Dai et al., 2007; Lamptey, 2008; Sapiano and Arkin, 2009; Roca et al., 2010; Jobard et al., 2011], but few of them focused on criteria relevant to the modeling of Sahel vegetation at a regional scale, which implies working at daily to decadal time steps over several years.

[6] The objective of the present work is to evaluate the skills of rainfall products when used in vegetation modeling over the Sahel. The evaluation includes (1) the intercomparison of three selected rainfall products on criteria relevant to vegetation growth modeling which, according to the literature [e.g., Rambal and Cornet, 1982; Sivakumar, 1992; Hiernaux et al., 2009], are the timing and amounts of rainfall on a daily time step, the timing and duration of dry spells, and the spatial pattern of the rainfall fields; and (2) the test of the selected rainfall products in vegetation growth simulations. To do so, three satellite-based precipitation products are chosen for their representativeness of current satellite-based rainfall products. They are intercompared over a wide region that include the Sahel $\left(10^{\circ} \mathrm{N}-\right.$ $20^{\circ} \mathrm{N}, 20^{\circ} \mathrm{W}-35^{\circ} \mathrm{E}$ ), and tested against rainfall maps derived by kriging from the network of rain gauge data available over a slightly smaller region $\left(10^{\circ} \mathrm{N}-17.5^{\circ} \mathrm{N}, 17.5^{\circ} \mathrm{W}-22.5^{\circ} \mathrm{E}\right)$ that encompasses the nine member countries of the Permanent Interstate Committee for Drought Control in the Sahel (CILSS).

[7] The different data sets are presented in section 2 , and the methodology for comparing these precipitation products is detailed in section 3. Section 4 describes the main results obtained for each criterion of comparison (spatial pattern, rainfall daily occurrence, and dry spell duration and distribution, and rainfall amounts), and section 5 illustrates how these different rainfall attributes have an impact on the numerical simulations of the Sahelian vegetation at a regional scale, especially by comparing simulated vegetation fields to vegetation index maps from satellite observations. A concluding discussion is given in section 6 .

\section{Precipitation Data Sets}

\subsection{Satellite Precipitation Products}

[8] Retrieving rainfall fields at fine scale - i.e., $10-50 \mathrm{~km}$ and $1-3 \mathrm{~h}$ resolutions - is highly challenging, especially in the Sahel. Great improvements in satellite-based rainfall estimation are provided by combining geostationary IR measurements with passive MW measurements. Indeed, if the satellite-borne MW instruments can provide rainfall rates with good accuracy, only two measurements per day are available at the same location because of the polar orbit of the satellite. Conversely, the geostationary IR satellites offer a quasi continuous temporal coverage but less precise quantitative information. More recently, active MW measurements (radar) have also been used aboard satellites for precipitation measurements, providing a more accurate estimate of rain intensities but with a lower time sampling than that of IR and passive MW satellites.

[9] Three rainfall precipitation products derived from satellite measurements have been selected with regard to their spatial and temporal resolution (Table 1). The Climate Prediction Center Morphing (CMORPH) [Joyce et al., 2004] and Tropical Rainfall Measuring Mission (TRMM) 3B42v.6 [Huffman et al., 2007] precipitation products are available at a spatial resolution of $0.25^{\circ} \times 0.25^{\circ}$ and a $3 \mathrm{~h}$ time step. Among the products that present the required temporal and spatial resolutions, CMORPH is considered as typical from the real-time products like Precipitation Estimation from Remotely Sensed Information using Artificial Neural Networks (PERSIANN) [Hsu et al., 1997] or TRMM RealTime product (TRMM3B42-RT) [Huffman et al., 2007]. In the same way, the TRMM3B42 is taken as representative of global well-calibrated products such as Global Satellite Mapping of Precipitation (GSMAP) [Ushio et al., 2006], besides the fact that TRMM3B42 is widely used by the scientific community [e.g., Boone et al., 2010; Bock et al., 2010; Yong et al., 2010]. The Rainfall Estimate (RFE2.0) product [Xie and Arkin, 1996] has a finer spatial resolution $\left(0.1^{\circ} \times 0.1^{\circ}\right)$ and a daily time step. It is chosen as a typical regional African rainfall product, like Estimation des Precipitations par Satellite-Seconde Generation (EPSAT-SG) [Berges et al., 2005].

[10] For these three products, the algorithms combine several types of measurements, mainly IR and MW, and two of them (RFE2.0 and TRMM3B42) also incorporate data from rain gauge measurements. These two last products 
Table 1. Main Characteristics of the Three Selected Precipitation Satellite Products ${ }^{\mathrm{a}}$

\begin{tabular}{|c|c|c|c|}
\hline $\begin{array}{l}\text { Data Set Name } \\
\text { (Reference) }\end{array}$ & $\begin{array}{l}\text { Spatial and Temporal } \\
\text { Resolution/Coverage }\end{array}$ & Data Sources & Online Documentation \\
\hline CMORPH [Joyce et al., 2004] & $\begin{array}{l}0.25^{\circ} \times 0.25^{\circ}-3 \text { hourly } \\
60^{\circ} \mathrm{N}-60^{\circ} \mathrm{S}, \text { global } \\
\text { Dec } 2002 \text { to present }\end{array}$ & $\begin{array}{l}\text { Microwave estimates (DMSP 13, } \\
14 \text { and } 15(\mathrm{SSM} / \mathrm{I}), \text { NOAA-15, } 16 \\
\text { and } 17 \text { (AMSU-B) and the } \\
\text { TRMM (TMI)) IR motion vectors } \\
\text { from geostationary satellites. }\end{array}$ & $\begin{array}{l}\text { http://www.cpc.ncep.noaa.gov/products/ } \\
\text { janowiak/cmorph_description.html }\end{array}$ \\
\hline RFE2.0 [Xie and Arkin, 1996] & $\begin{array}{l}0.1^{\circ} \times 0.1^{\circ}-\text { daily } \\
40^{\circ} \mathrm{N}-40^{\circ} \mathrm{S} \\
20^{\circ} \mathrm{W}-55^{\circ} \mathrm{E} \\
\text { Jan } 2001 \text { to present }\end{array}$ & $\begin{array}{l}\text { Microwave estimates (SSM/I, AMSU-B) } \\
\text { IR estimates from geostationary satellites } \\
\text { GTS station data }\end{array}$ & $\begin{array}{l}\text { http://www.cpc.ncep.noaa.gov/products/ } \\
\text { fews/RFE2.0_desc.shtml }\end{array}$ \\
\hline TRMM3B42 [Huffman et al., 2007] & $\begin{array}{l}0.25^{\circ} \times 0.25^{\circ}-3 \text { hourly } \\
50^{\circ} \mathrm{N}-50^{\circ} \mathrm{S} \\
\text { global Jan } 1998 \text { to } \\
\text { present }\end{array}$ & $\begin{array}{l}\text { Microwave estimates (TRMM, SSM/I, } \\
\text { AMSR and AMSU), IR estimates } \\
\text { from geostationary satellites, Monthly } \\
\text { rain gauge analysis }\end{array}$ & $\begin{array}{l}\text { http://disc.gsfc.nasa.gov/documentation/ } \\
\text { TRMM_README/ } \\
\text { TRMM_3B42_readme.shtml }\end{array}$ \\
\hline
\end{tabular}

${ }^{\text {a }}$ See text for details on acronyms (adapted from Dai et al. [2007]).

have already demonstrated good skills over the Sahelian belt when compared with rain gauge observations in terms of precipitation distribution and basic statistical parameters [e.g., Jobard et al., 2011; Roca et al., 2010], which justify the present effort to better characterize their ability as input in vegetation modeling. The CMORPH product has been selected to investigate the confidence that could be expected from near-real-time vegetation modeling.

\subsubsection{Tropical Rainfall Measuring Mission Product 3B42v.6 (TRMM3B42)}

[11] The TRMM started in 1997 in a partnership between National Aeronautics and Space Administration (NASA) and Japan Aerospace Exploration Agency (JAXA). First, each MW satellite observation (SSM/I, Special Sensor Microwave Imager; TMI, TRMM Microwave Imager; AMSR, Advanced Microwave Scanning Radiometer; and AMSU, Advanced Microwave Sounding Unit) is converted to rainfall estimate using its proper algorithm. Then the microwave precipitation estimates are calibrated and combined (using probability matching of precipitation rate histograms). Then, IR precipitation estimates (GMS, Geostationary Meteorological Satellite; GOES, Geostationary Operational Environmental Satellite, Meteosat; and NOAA-12, National Oceanic and Atmospheric Administration) are created using the calibrated MW precipitation, and the MW and IR estimates are combined. As a last step, monthly accumulated rain gauge data from the Climate Assessment and Monitoring System (CAMS) produced by NOAA Climate Prediction Center (CPC) and rain gauge product from the Global Precipitation Climatology Center (GPCC) are incorporated [Huffman et al., 2007] (Table 1).

\subsubsection{Rainfall Estimate 2.0 (RFE2.0)}

[12] The RFE2.0 product was developed at NOAA by the CPC [Xie and Arkin, 1996]. The algorithm merges IR (GOES), passive MW (AMSU, SSM/I), and gauge measurements as follows: each type of satellite observation is converted to a rainfall estimate using its proper algorithm, then weights are calculated for each satellite rainfall estimate by comparison to gauge measurements (when and where they are available). The rainfall estimates are combined using these weights to remove random error. Then systematic bias is eliminated by adjusting the relative distribution previously obtained to gauge measurements which provide the magnitude of the rainfall field. As mentioned in Table 1, the gauges used in this algorithm are the ones belonging to the Global Telecommunication System (GTS) network, which consists of about 1000 operating gauges in Africa.

\subsubsection{CPC MORPHing (CMORPH)}

[13] The CMORPH product [Joyce et al., 2004] has been developed by the NOAA CPC. The algorithm is based on a combination of passive MW observations from loworbited satellites (the TMI, three SSM/I, three AMSU, and one AMSR) with spatial propagation information deduced from IR observations obtained by geostationary satellites (Meteosat) (Table 1). More precisely, MW observations are converted to cloud features and rainfall estimates. When no passive MW data are available, the cloud features previously obtained are propagated by motion vectors derived from IR imagery, and then morphed using a linear combination of weights regarding the time from the nearest passive MW sensor. Thus, in this algorithm, IR imagery is not used to estimate rainfall but to derive motion vectors.

\subsection{Gauge Data}

[14] Three networks of rain gauges are working in the Sahel. The whole operational CILSS network is composed of about 600 rain gauges located in nine African countries (Burkina-Faso, Mali, Niger, Senegal, Cape-Verde Islands, Gambia, Guinea-Bissau, Chad, and Mauritania). The AGRométéorologie-HYdrologie-METéorologie (AGRHYMET) regional center (CRA) manages a monitoring network composed of about 250 rain gauges that is included in the CILSS network. The data are available on a 10-day basis at the CRA. The synoptic network (SYNOP) is composed of 80 rain gauges, and data are available on a daily basis through the GTS. This network is included in the CRA network [Ali et al., 2005b].

[15] The average number of gauges from these networks is around 600, but it can vary significantly from one year to another [Ali and Lebel, 2008]. The present localization of the CILSS and SYNOP stations is provided on Figure 1. These networks have a relatively dense coverage at the regional scale with a density of approximately one station per $3500 \mathrm{~km}^{2}$. However, the stations are not homogeneously distributed over the region. The network is sparser in the northern part of the area, and no data are available over Nigeria $\left(10^{\circ} \mathrm{N}-12.5^{\circ} \mathrm{N}, 4^{\circ} \mathrm{E}-14^{\circ} \mathrm{E}\right)$.

[16] After testing different kriging algorithms, Ali et al. [2005a] proposed a method to deliver optimized interpolated precipitation fields based on the measurements from 


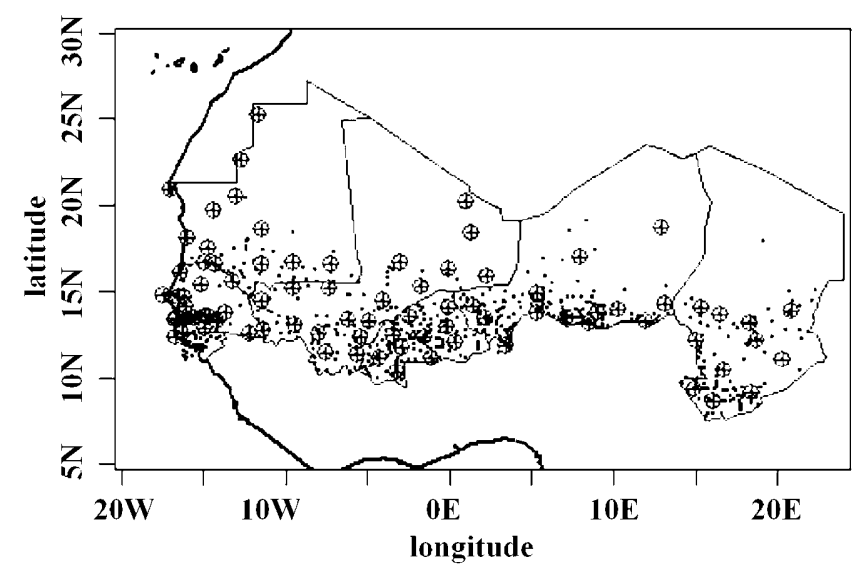

Figure 1. Location of the CILSS (dots) and the synoptic network (encircled crosses) rain gauge stations (adapted from Ali and Lebel [2008]).

these networks. These interpolated fields are produced at a spatial resolution of $0.5^{\circ} \times 0.5^{\circ}$ with a 10 -day time step. They extend from $10^{\circ} \mathrm{N}$ to $17.5^{\circ} \mathrm{N}$ and from $17.5^{\circ} \mathrm{W}$ to $22.5^{\circ} \mathrm{E}$, except for the year 2007 for which they cover the area ranging between $17.25^{\circ} \mathrm{W}-22.25^{\circ} \mathrm{E}$ and $10.25^{\circ} \mathrm{N}-$ $20.25^{\circ} \mathrm{N}$.

[17] Since the kriged data are not real ground truth, they carry an uncertainty that might bias comparisons with other rainfall field estimates [Laurent et al., 1998; Lebel and Amani, 1999; Ali et al., 2005b]. These interpolations of rain gauge measurements will be, in a certain extent, considered in this study as the "best estimate" against which satellite-based products are compared, as shown by Ali et al. [2005b]. However, the possible bias due to the scarcity of the rain gauge network must be kept in mind since the uncertainty on rainfall estimates depends strongly on the rain gauge network density and on the duration of aggregation [Lebel and Le Barbé, 1997].

\section{Methodology}

[18] Both the intercomparison of three satellite-derived rainfall products and the test of these products with the map of precipitation fields interpolated from rain gauge data are performed with several criteria relevant to vegetation modeling in the Sahel. As indicated in section 2.2, the rainfall fields resulting from kriging rain gauge data cannot be considered as "the truth" since they can present strong uncertainties, particularly when rainfall is weak and gauges density is low, as in northern Sahel (north of latitude $15^{\circ} \mathrm{N}$ ) and at the edges of the rainy seasons [Ali et al., 2005a, 2005b]. To deal with these limitations, Jobard et al. [2011] decided to retain only grid cells with at least one gauge in it, but only $21 \%$ of the grid cells satisfy this condition over the June to September periods from 2004 to 2006. Moreover, the kriged data are only available at a 10-day time scale, which does not enable comparisons to be performed on the daily distribution of the rainfall and the timing of dry spells. For these two reasons (sparsity of the gauge network in the north of the area and decadal time step), intercomparisons between the different satellite-based products are performed to provide useful information that complements results obtained with the kriged-satellite products comparison. Indeed, although they are based on similar measurements (IR and MW satellite observations, and rain gauges for two of them), the three selected satellite products are established with different algorithms. The consistency between the three products is thus investigated first. The comparison with interpolated gauges measurements enables to estimate the quality of the satellite-based products in terms of agreement with ground-based data sets.

[19] As emphasized by Laurent et al. [1998], each criterion can lead to a different ranking of the products; it is thus important to consider a range of criteria. Here, three criteria are selected: the spatial pattern of rain fields that should contribute to retrieve the spatial pattern of vegetation growth at a regional scale; the frequency of rainy days and the occurrence of dry spells because of the strong sensitivity of Sahelian vegetation to the temporal distribution of the rain [see e.g., Rambal and Cornet, 1982; Sivakumar, 1992; Frappart et al., 2009]; and the precipitation amounts as a driver of vegetation growth and amount [Mougin et al., 1995; Tracol et al., 2006]. For each of these three criteria, the comparison is carried out following Hossain and Huffman [2008], by answering the following questions: how does the quality of the products vary in space? how does this quality vary through time? and what is the quantitative difference between the products?

[20] The comparison is carried out over 4 years, 2004 to 2007. This duration is a compromise between the availability of the different data sets and the minimum duration required to take into consideration, at least in part, the interannual variability of the precipitation in the Sahel region [see e.g., Ali and Lebel, 2008]. In each year, the investigated period is restricted to the rainy season, i.e., from May to October, as in the study by Ali et al. [2005b]. The intercomparisons of satellite-based rainfall products have been performed over the whole Sahelian belt $\left(10^{\circ} \mathrm{N}-\right.$ $20^{\circ} \mathrm{N} ; 20^{\circ} \mathrm{W}-35^{\circ} \mathrm{E}$ ). The kriged rain gauge data sets being available only from $10^{\circ} \mathrm{N}$ to $17.5^{\circ} \mathrm{N}$ and from $17.5^{\circ} \mathrm{W}$ to $22.5^{\circ} \mathrm{E}$, the comparisons between the satellite products and these data sets have been restricted to this area. CMORPH and TRMM3B42 products are both provided with a spatial resolution of $0.25^{\circ} \times 0.25^{\circ}$ and can therefore be compared directly at this resolution. Besides, the resolution of the RFE2.0 product is finer $\left(0.1^{\circ} \times 0.1^{\circ}\right)$. However, for the sake of consistency, the RFE2.0 product has been aggregated at the same resolution of $0.5^{\circ} \times 0.5^{\circ}$ as CMORPH and TRMM3B42. The time scales used in the intercomparison of satellite products range from 1 to 10 days, depending on the data sets. Because of the resolution of the data set, the comparisons with rain gauge kriged data are performed at a spatial resolution of $0.5^{\circ} \times 0.5^{\circ}$ with a temporal resolution of 10 days. The results of the tests on the structure, frequency, dry spells, and amounts of the precipitation fields are successively presented in section 4 .

\section{Results}

\subsection{Spatial Structure of the Precipitation Fields}

[21] The first step of our analysis is to check the global consistency between the different satellite-based precipitation products and of these satellite products with the kriged data. Although the good skills of the selected products have 
Table 2. Characteristics of the Distribution of the Annual Mean Rainfall for CMORPH, RFE2.0, and TRMM3B42 Averaged Over the Rainy Season (May to October) Over the Period 2004-2007 and Over the Area $10^{\circ} \mathrm{N}-20^{\circ} \mathrm{N} ; 20^{\circ} \mathrm{W}-35^{\circ} \mathrm{E}$

\begin{tabular}{lcccc}
\hline & Mean $(\mathrm{mm})$ & Median $(\mathrm{mm})$ & Max $(\mathrm{mm})$ & Mean/Max \\
\hline CMORPH & 527 & 354 & 2409 & 0.22 \\
RFE2.0 & 314 & 266 & 1177 & 0.27 \\
TRMM3B42 & 303 & 256 & 1419 & 0.21 \\
\hline
\end{tabular}

been demonstrated by Roca et al. [2010] and Jobard et al. [2011], this step is performed to confirm these results over the Sahel region from 2004 to 2007, which are wider and longer than in the previous studies. The objectives of this section are (1) to check the location and the extent of the rainfall fields and the consistency of their relative proportions and (2) to estimate the consistency of the temporal variation of the structure of the rainfall fields between the products. This is performed by examining (1) the spatial distribution of the precipitation cumulated over the 4-year period and (2) the average temporal variation of the normalized precipitation rates.

\subsubsection{Satellite-Based Products Intercomparison 4.1.1.1. Spatial Distribution of the Rainfall Field}

[22] The consistency of the spatial distribution of the precipitation fields is first examined at the regional scale. To this end, the precipitation fields from each product are cumulated over the four rainy seasons (values over oceanic areas are disregarded). In order to minimize the variability due to differences in rainfall intensity between the satellite products, the cumulated precipitations are normalized to their respective maximum over the whole studied area.

[23] The consistency of precipitation fields at regional scale is checked by examining the distribution of the annual mean rainfall for the rainy season (May to October) averaged over the period 2004-2007 (Table 2). The CMORPH distribution is much more stretched than those of the two other satellite products, with a mean value of $527 \mathrm{~mm}$, against $303 \mathrm{~mm}$ for TRMM3B42 and $314 \mathrm{~mm}$ for RFE2.0, and a maximum value of $2409 \mathrm{~mm}$, against $1419 \mathrm{~mm}$ for TRMM3B42 and $1177 \mathrm{~mm}$ for RFE2.0. However, the mean/maximum ratio is similar for $\mathrm{CMORPH}$ and TRMM3B42 (0.22 and 0.21$)$, while it is slightly higher for RFE2.0 (0.26), indicating that this product shows more frequent high-precipitation events.

[24] The three satellite-based precipitation products provide similar spatial structure of rainfall fields over the Sahel (Figure 2). Especially, both the northern limit of observed precipitations (located around $18^{\circ} \mathrm{N}$ in the western part and $15^{\circ} \mathrm{N}$ in the eastern part) and the location of the relative maxima (located around $15^{\circ} \mathrm{W}$ and $12^{\circ} \mathrm{N}$ and around $8^{\circ} \mathrm{E}$ and $10^{\circ} \mathrm{N}$ ) are clearly coherent in the three products. On the other hand, some differences are observed in the southern part of the area between $20^{\circ} \mathrm{E}$ and $30^{\circ} \mathrm{E}$ with very low normalized precipitation values for TRMM3B42, while CMORPH and RFE2.0 products suggest relatively high precipitation in that area. Nevertheless, the spatial structures of all three satellite-based precipitation products are largely coherent.

\subsubsection{Ten-Day Rainfall Variability}

[25] To evaluate the consistency between the different satellite products through time, the spatial correlation coef- ficients between pairs of satellite products are computed every 10-day period from May to October over the 4-year period. As already pointed out by Laurent et al. [1998], the correlation coefficient measures the cofluctuation of the products and is not sensitive to bias.

[26] The computed correlation coefficients range between 0.6 and 0.9 (for $\mathrm{n} \sim 8000$ for CMORPH/TRMM3B42, $\mathrm{n} \sim 2000$ for CMORPH/RFE2.0 and TRMM3B42/RFE2.0), indicating a significant level of coherence at the decadal time step between the different data sets. Moreover, the values of the correlation coefficients do not vary significantly along the rainy season nor during the 4-year period: for a given year, the standard deviation of the correlation coefficient is around 5\% of its annual mean for CMORPH/ RFE2.0 and CMORPH/TRMM3B42, and around $8 \%$ for TRMM3B42/RFE2.0. They are also stable from one year to the other: for each couple of satellite-based products, the standard deviation of the annual means is $\sim 2 \%$ of the 4-year global mean. It must be noted that the correlation coefficients are more scattered in 2005 (with CMORPH/TRMM3B42 having the lowest values), and to a lesser extent in 2007. These results suggest that the quality of the satellite products remains relatively constant from the intraseasonal to the interannual time scales.

\subsubsection{Comparison with Kriged Rain Gauge Fields} 4.1.2.1. Spatial Comparison

[27] The three satellite products are compared with the precipitation fields derived from kriged gauge measurements (further referred as "kriged fields"). In a first step, the comparison is performed on the cumulated and normalized precipitation fields, for the area over which kriged fields are available, i.e., about one half of the area previously concerned for the satellite-based precipitation products comparisons. The kriged fields over most of Nigeria (see Figure 2, white box), are excluded from the analysis since no gauge measurements were available from this country.

[28] For each product, the distribution of the 4-year mean rainfall field was first examined over the area where rain gauge measurements are available (Table 3). As already observed over the large domain, the CMORPH distribution is much more stretched than those of the two other rainfall satellite products with a mean value of $770 \mathrm{~mm}$, against $445 \mathrm{~mm}$ for TRMM3B42, $453 \mathrm{~mm}$ for RFE2.0, and $424 \mathrm{~mm}$ for the kriged fields. The maximum values are $2409 \mathrm{~mm}$ for CMORPH, $1419 \mathrm{~mm}$ for TRMM3B42, $1177 \mathrm{~mm}$ for RFE2.0, and $1330 \mathrm{~mm}$ for the kriged fields. The mean/ maximum ratio is similar for CMORPH, TRMM3B42, and the kriged fields $(0.32,0.31$, and 0.32$)$, while it is again slightly higher for RFE2.0 (0.38).

[29] The main patterns of the rainfall fields are similar for the kriged fields and the satellite products (Figure 2). The relative maxima of precipitations are located in the southeastern and southwestern parts of the studied area for all precipitation data sets. However, some disagreements are observed in the southwestern part of the area, where the extent of high precipitation is larger on kriged fields than on the satellite-based rainfall fields. Note that the density of the gauge network is important in this region, and thus, the confidence level of the associated kriged fields is high. On the other hand, the computation of the kriged fields should yield a smoother spatial pattern of precipitation fields, and 

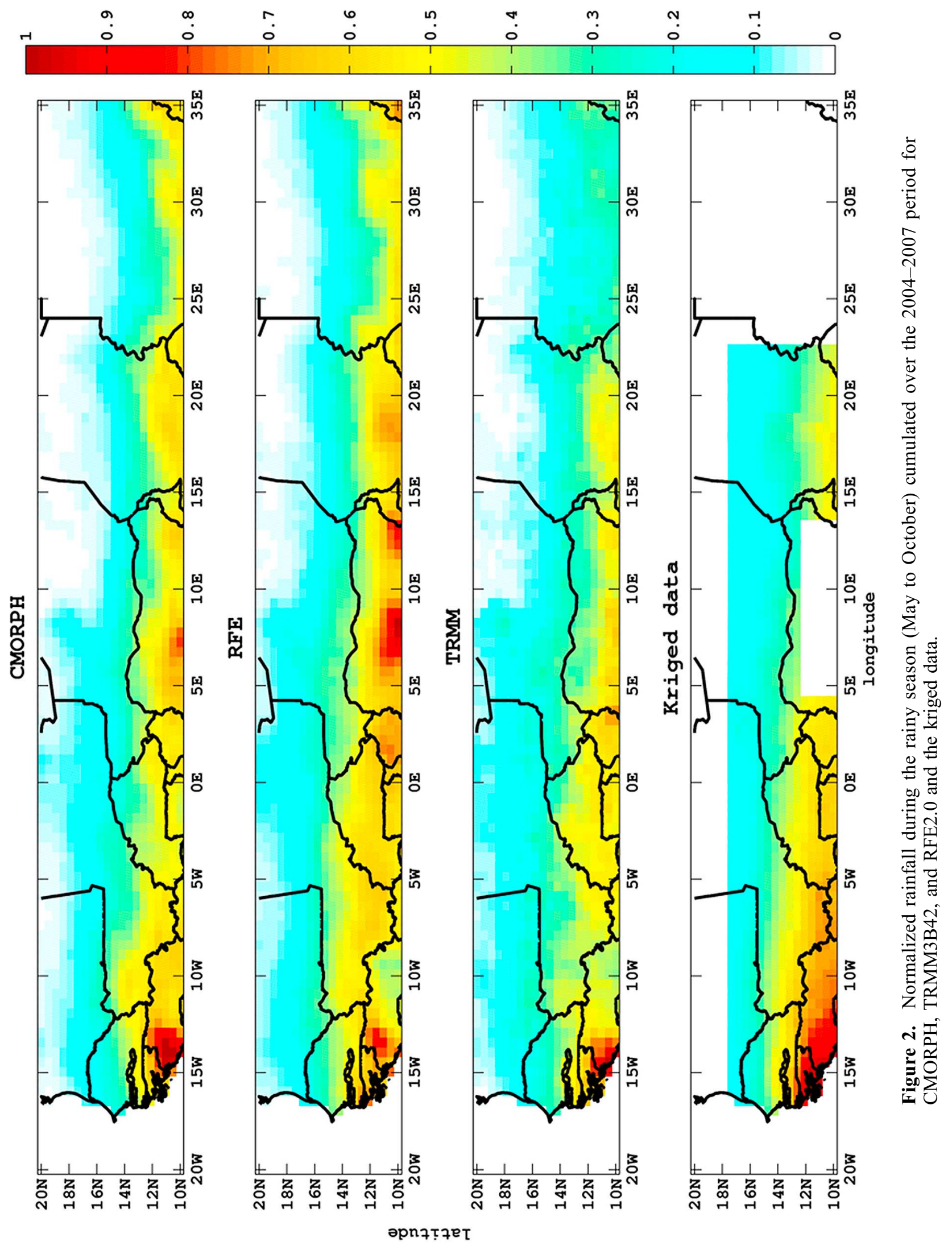
Table 3. Characteristics of the Distribution of the Annual Mean Rainfall for the Kriged Data and CMORPH, RFE2.0, and TRMM3B42, Averaged Over the Rainy Season (May to October) Over the 2004-2007 Period and Over the Area $10^{\circ} \mathrm{N}-17.5^{\circ} \mathrm{N}$; $17.5^{\circ} \mathrm{W}-22.5^{\circ} \mathrm{E}$

\begin{tabular}{lcccc}
\hline & Mean $(\mathrm{mm})$ & Median $(\mathrm{mm})$ & Max $(\mathrm{mm})$ & Mean/Max \\
\hline Kriged data & 424 & 430 & 1330 & 0.32 \\
CMORPH & 770 & 741 & 2409 & 0.32 \\
RFE2.0 & 453 & 444 & 1177 & 0.38 \\
TRMM3B42 & 445 & 438 & 1419 & 0.31 \\
\hline
\end{tabular}

this can partly explain the differences observed between kriged fields and satellite-based rainfall fields in this area.

\subsubsection{Ten-Day Variability}

[30] The spatial correlation coefficients between the decadal rainfall fields derived from satellite-based precipitation products and the kriged fields are computed from 2004 to 2007 (not shown; n 1200). The resulting correlation coefficients are lower than those obtained for the intercomparison of the different satellite-based precipitation products. They range approximately between 0.3 and 0.9 (against 0.6 to 0.9 for the intercomparison), and about $9 \%$ of the values are lower than 0.6. The correlation coefficient is particularly weak from May to August 2005 for the TRMM3B42. However, these correlation coefficients remain largely significant, indicating an overall good agreement between satellite-based precipitation products and kriged fields. By taking into account estimation error uncertainty, especially sampling error [Gebremichael and Krajewski, 2004, 2005], comparisons would yield to even higher correlation coefficients [see Roca et al., 2010].

[31] The correlation coefficients are stable over the rainy season: for a given year, the standard deviation of the correlation coefficient is $\sim 10 \%$ of its annual mean for CMORPH and RFE2.0 (against 8\% for satellite products only) and $12 \%$ to $27 \%$ for TRMM3B42. When averaged over the rainfall season (May to October), the correlation coefficients are stable from one year to another: for the CMORPH and RFE2.0 products, the standard deviation of its annual mean is about $2 \%$ of the 4 -year global mean. This variability of the correlation coefficients is higher for the TRMM3B42 product, with a standard deviation of its annual mean of $8 \%$ of the 4 -year global mean, mainly because of the poor agreement observed for 2005 .

\subsubsection{Conclusion Concerning the Spatial Structure of the Precipitation Field}

[32] The three selected satellite-based precipitation products provide coherent spatial structure of the rainfall fields over the whole Sahel. Moreover, the comparisons between these satellite products and the gauge-interpolated measurements, even if they have been performed over a smaller area, suggest that the structures provided by the satellite products are also in good agreement with precipitation fields derived from gauge measurements. This reinforces the results obtained by previous studies on smaller areas and shorter periods [Roca et al., 2010; Jobard et al., 2011].

\subsection{Rainfall Frequency and Dry Spells}

[33] As shown by Dai et al. [2007], the spatial distribution of total precipitation amounts is first determined by the number of rain events at different locations, and second, by how much it rains during these events. Moreover, rainfall frequency and dry spell occurrences are critical issues for vegetation growth. This has already been pointed out among others by Ali et al. [2005b] for crops. The aim of this section is to check if the rainy days and the dry spells occur at the same time for a same location, and in the same proportions for the three satellite-based rainfall products. Since kriged fields are only available at the 10-day time scale (which is not sufficient to work on rainy days or to detect short dry spells), this analysis is carried out on a daily basis, but between satellite products only. The annual number of rainy days is assessed separately for each rainy season 2004-2007 and for each satellite-based precipitation products (Figure 3). The mean annual values vary between approximately 100 and 150 rainy days (for a 184-day period) at the very south of the studied area to 0 rainy day at its northeastern edge. CMORPH and RFE2.0 show very similar patterns, while the TRMM3B42 product provides a lower number of rainy days, especially over the $10^{\circ} \mathrm{N}-12^{\circ} \mathrm{N}$ latitudinal band.

\subsubsection{Satellite Based Precipitation Products}

\subsubsection{Global Scores}

[34] The consistency of the rainfall frequency provided by the satellite-based precipitation products has been quantified by computing an agreement score between the different products in terms of the detection of rainy days (rainfall $>$ $0 \mathrm{~mm}$ ) or nonrainy days (rainfall $=0 \mathrm{~mm}$ ). These scores (expressed in percent) have been computed for each pixel and for the 4-year period of interest (2004-2007) over the Sahel. Four cases have been distinguished: (1) the two satellite products $\mathrm{A}$ and $\mathrm{B}$ agree on the rainy day $(\mathrm{y} / \mathrm{y})$; (2) the two satellite products A and B agree on the nonrainy day $(\mathrm{n} / \mathrm{n})$; (3) product $\mathrm{A}$ indicates a rainy day, but product $\mathrm{B}$ does not $(\mathrm{y} / \mathrm{n})$; and (4) product $\mathrm{A}$ indicates a nonrainy day and product $B$ indicates a rainy day $(n / y)$. These categories can be compared with the False Alarm Ratio (FAR) and the Probability of Detection (POD) as defined in Ebert et al. [2007]. However, since we do not have any absolute reference here in terms of daily rain detection, we preferred to use explicit names of the different cases.

[35] The scores corresponding to agreements for rainy $(y / y)$ or nonrainy days $(\mathrm{n} / \mathrm{n})$ are high (about $80 \%$ when summed) for the three pairs of satellite products (Figure 4). These scores are almost equally driven by the rainy and the nonrainy cases, the number of $y / y$ cases being slightly lower than the number of $n / n$ cases. Concerning the cases of disagreement (y/n and $\mathrm{n} / \mathrm{y})$, it can be noted that RFE2.0 detects more rainy days than CMORPH, which detects more rainy days than TRMM3B42 (as also observed in Figure 3). Since the mean annual rainfall was higher for CMORPH than for RFE2.0 (see Tables 2 and 3 ), this suggests that the precipitation events are of lower intensity for RFE2.0 than for CMORPH.

[36] A complementary insight about the consistency of rain distribution between the studied products bears on the dry spell analysis. Usually, a dry spell is defined as a period of consecutive days without rain, embedded in the rainy season [e.g., Sivakumar, 1992; Frappart et al., 2009]. A threshold can be defined to detect the next rainy day that ends the current dry spell. A criterion has also to be defined to detect the beginning of the rainy season or the date of a possible germination, in order to reduce the analysis to the sensitive period for vegetation. 


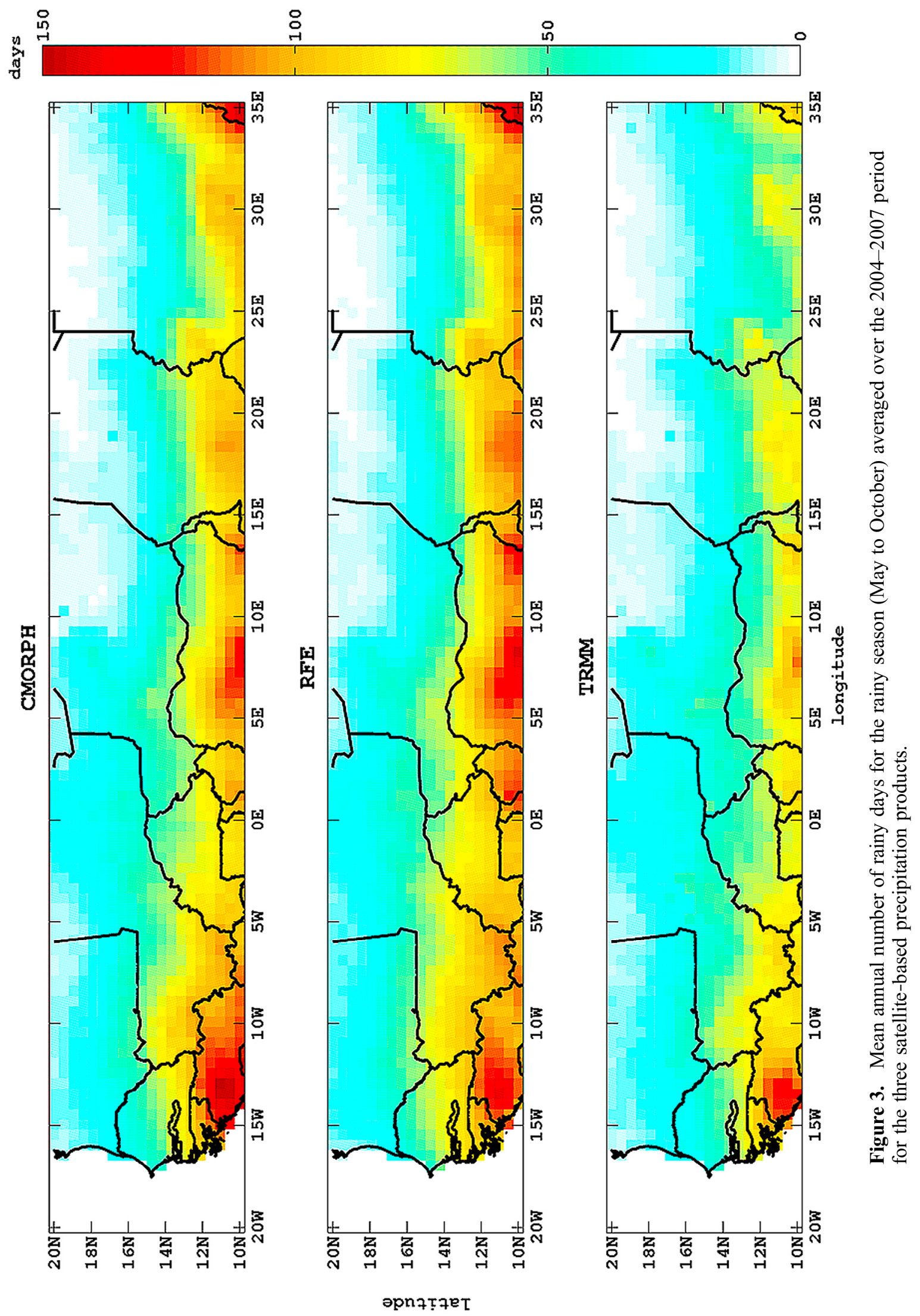




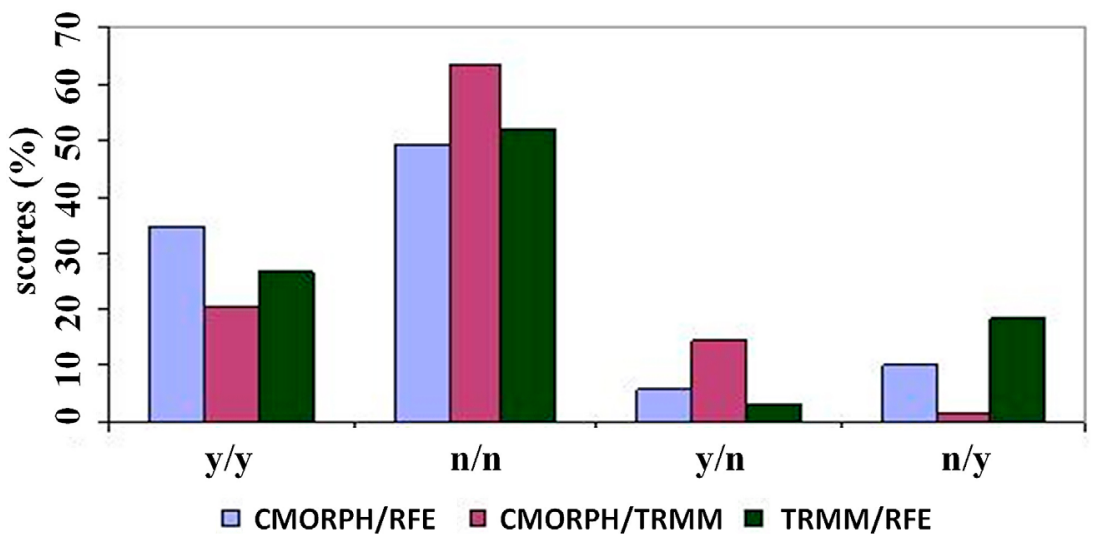

Figure 4. Agreement between daily satellite-based precipitation products for the detection of rainy days (y/y, agreement on rainy day; $\mathrm{n} / \mathrm{n}$, agreement on not rainy day; $\mathrm{y} / \mathrm{n}$, disagreement rainy/not rainy day; $\mathrm{n} / \mathrm{y}$, disagreement not rainy/rainy day), computed from May to October for the 2004-2007 period and over the area $10^{\circ} \mathrm{N}-20^{\circ} \mathrm{N} ; 20^{\circ} \mathrm{W}-35^{\circ} \mathrm{E}$.

[37] Based on the work of Sivakumar [1992] and Frappart et al. [2009], it was decided to define the date of possible germination by the first day after 1 May when rainfall is at least $12 \mathrm{~mm}$ or when rainfall accumulated over 5 days is at least $20 \mathrm{~mm}$. The analysis is carried out until the end of September, since October matches with the senescence stage, when annual vegetation is not sensitive anymore to dry spells. Moreover, a very simple hydrologic budget is computed by subtracting an evapotranspiration of $2 \mathrm{~mm}$ per day [see Ramier et al., 2009]. Here, a dry spell is thus defined as consecutive days with a null hydrologic budget.
[38] The global mean dry spell distribution over the 2004 2007 seasons restricted as described above is expressed in terms of the relative area concerned by dry spells by counting the number of grid cells concerned for each dry spell duration and dividing it by the total number of grid cells (Figure 5). Similar behavior is observed from the three selected satellite-based rainfall products: dry spells shorter than 4 days are numerous (over $20 \%$ to $35 \%$ of the area), then the distribution shows a strong decrease (5-day dry spell represents about $5 \%$ to $10 \%$ of the area), and a continuous decay for longer dry spell (dry spells longer than 20 days bring a very small contribution). The proportion

Mean dryspell distributions

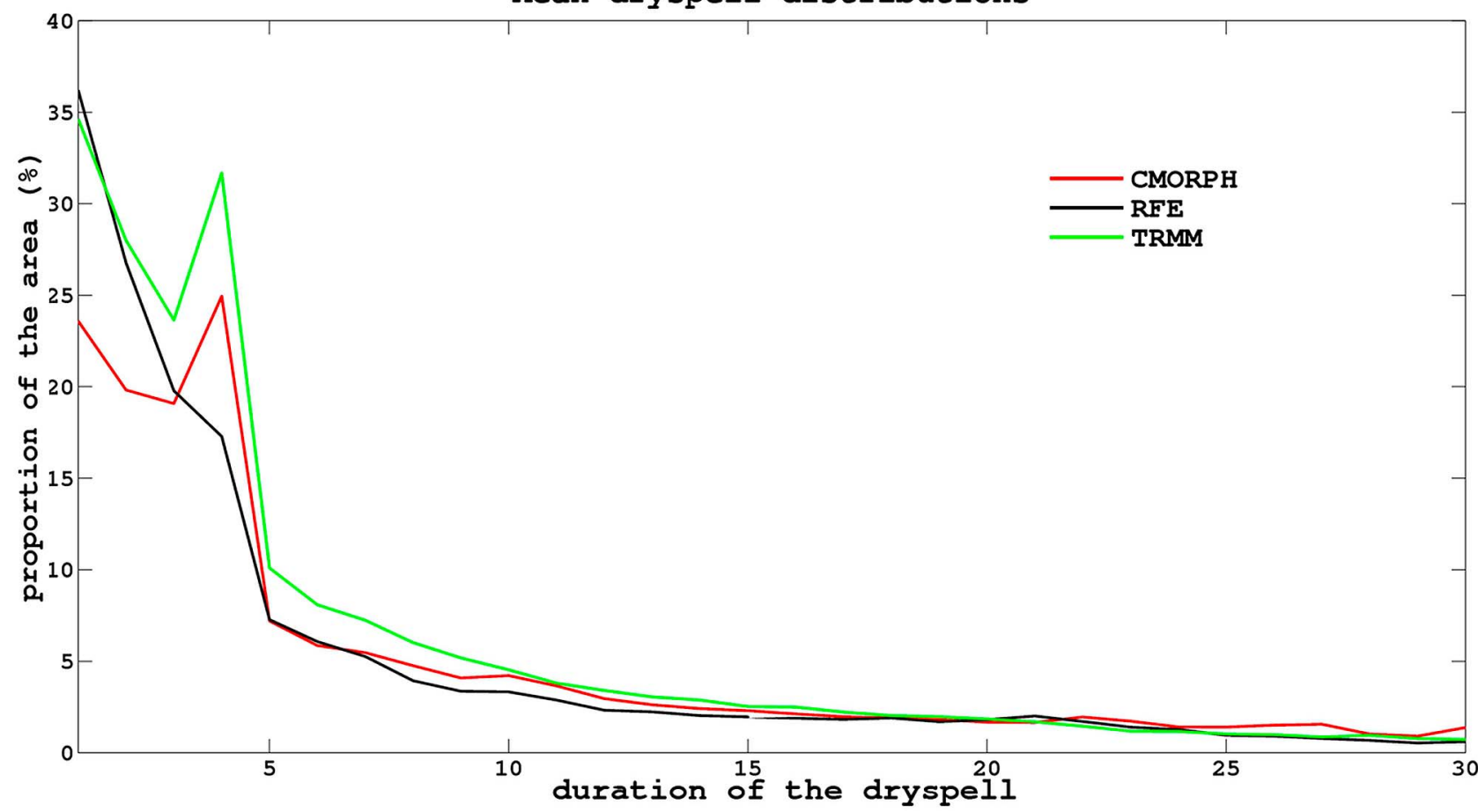

Figure 5. Mean dry spell distribution normalized to the studied area, over 2004-2007 restricted to the vegetation growth period. 


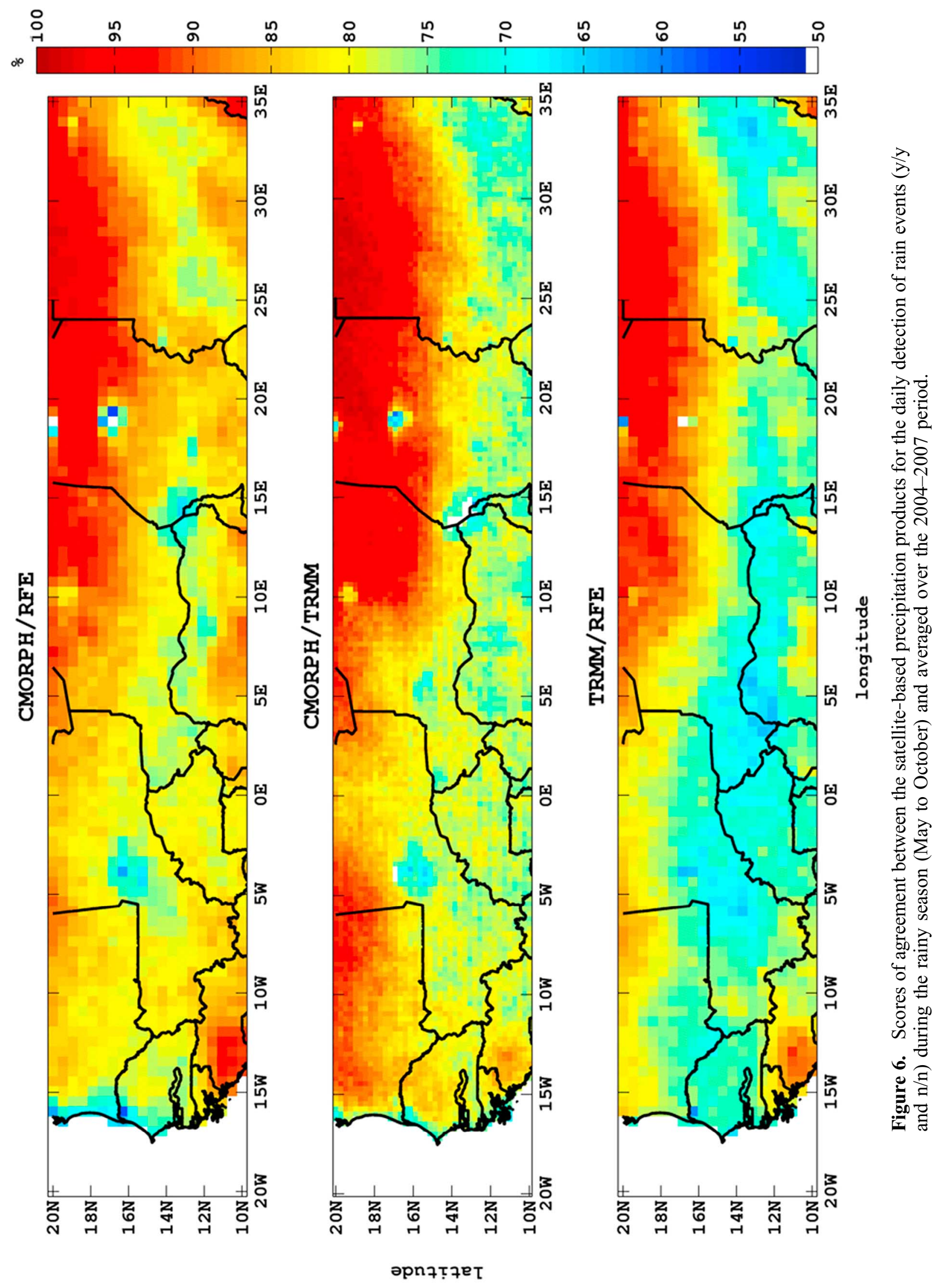



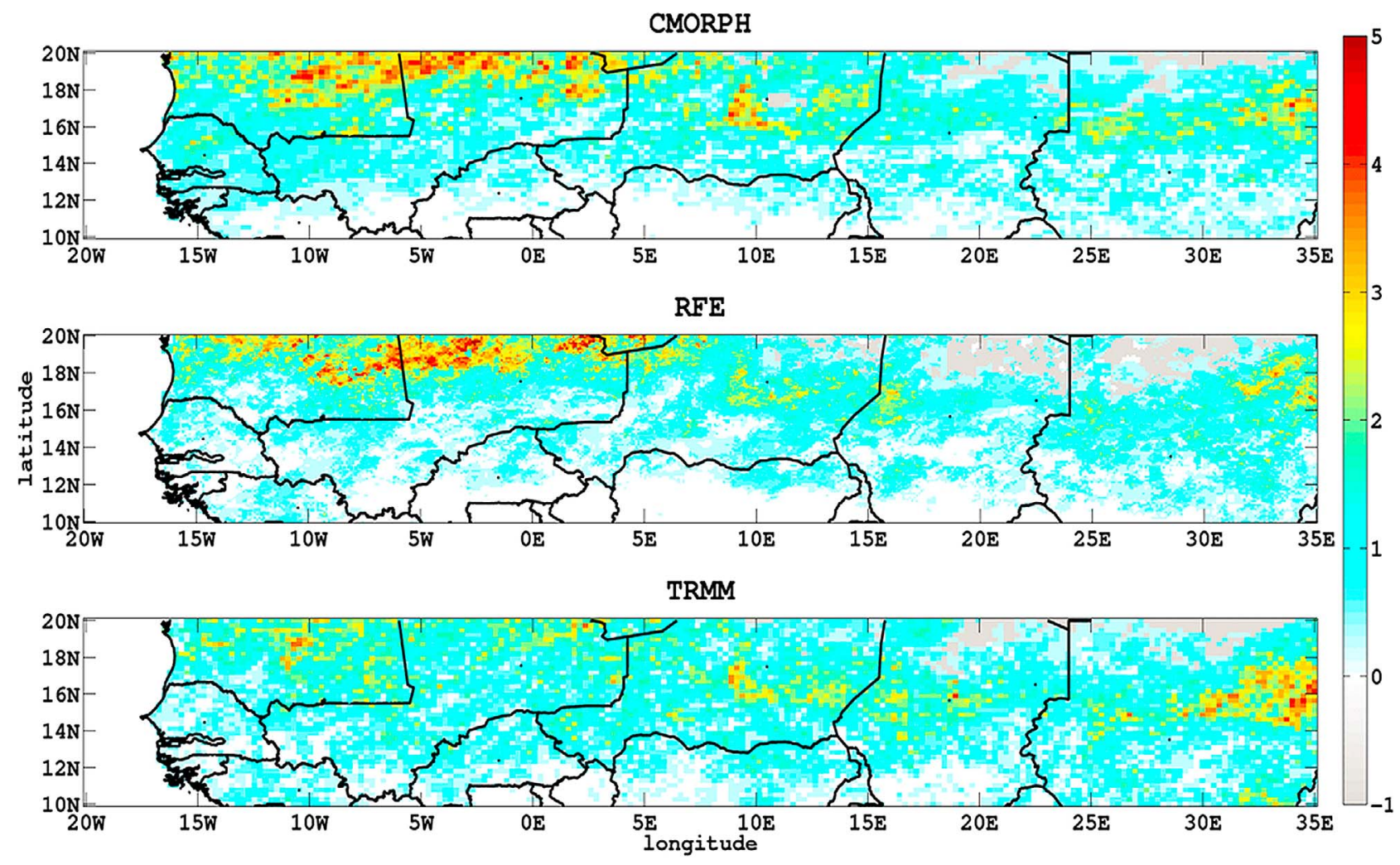

Figure 7. Mean annual number of dry spells lasting 5 days or more for the three satellite-based precipitation products, over 2004-2007 restricted to the vegetation growth period. (Gray cells correspond to areas where the germination criterion is never met.)

of the studied area concerned by dry spells is of the same order for the three products. However, there is a local maximum in the distribution for the 4-day dry spells for TRMM3B42 and CMORPH, which does not appear for RFE2.0. All these observations remain valid when performing a year-by-year analysis (not shown).

\subsubsection{Spatial Comparison}

[39] The scores of agreement ( $y / y$ and $n / n)$ of the different satellite-based precipitation products have been cumulated for the four rainy seasons and are displayed on maps (Figure 6). Large parts of the area $(76 \%, 60 \%$, and $37 \%$ for CMORPH/ RFE2.0, CMORPH/TRMM3B42 and TRMM3B42/RFE2.0, respectively) show agreement greater than $80 \%$. The higher levels of agreement are reached over the regions where precipitations are either very high (central south of the area) or very weak (northern part of the area).

[40] The minimum score is about $40 \%$. For the three pairs of satellite-based precipitation products, the agreement scores are lower (but still higher than $50 \%$ ) between $14^{\circ} \mathrm{N}$ and $16^{\circ} \mathrm{N}$, i.e., the zone corresponding to the northern limit of the precipitation and along the Atlantic Ocean coast. Smaller areas of disagreement are located in regions including water bodies such as Lake Chad $\left(13^{\circ} \mathrm{N}, 15^{\circ} \mathrm{E}\right)$. This is likely due to a "mixed pixel" effect (pixels over Lake Chad are considered as coastal water or coastal land) which reinforces the inconsistency due to the differences between the proper algorithms of the three products: propagation of passive MW along the motion vectors derived from IR measurements for CMORPH, weighted mean of $\mathrm{MW}$ retrieval and IR-based estimates (adjusted by monthly gauge data at nearby location) for TRMM3B42, and a similar methodology for RFE2.0 (adjusted by daily gauge data) but with different sets of passive MW and IR estimations derived from a different technique. The lowest agreement scores are obtained for the couple TRMM3B42/RFE2.0. This is consistent with the global scores given in the previous section, indicating that the RFE2.0 product detects more rainy days than TRMM3B42. Besides water bodies, disagreements are thus located over areas of intermediate rainfall amounts.

[41] The geographical pattern of the mean annual number of dry spells lasting 5 days or more (Figure 7) brings complementary information. As expected, a north-south gradient appears, with more dry spells at the northwest of the area (with a lighter extent for TRMM3B42), and almost none at its southern edge. Numerous dry spells are also observed between $30^{\circ} \mathrm{E}$ and $35^{\circ} \mathrm{E}$ at $16^{\circ} \mathrm{N}$, particularly for the TRMM3B42 product. Gray cells correspond to "always-dry" zones (where the germination criterion is never met); these gray cells are least numerous for the CMORPH product. In other words, slight differences are observed between products in terms of spatial repartition of the dry spells, particularly in zones where vegetation is the least likely to develop (north and east). A specific analysis of the impacts of these differences on vegetation simulations is carried out further.

\subsubsection{Daily Variability}

[42] To evaluate the temporal variability of the agreement in detecting rainy days, scores of agreement (y/y and $n / n)$ or 

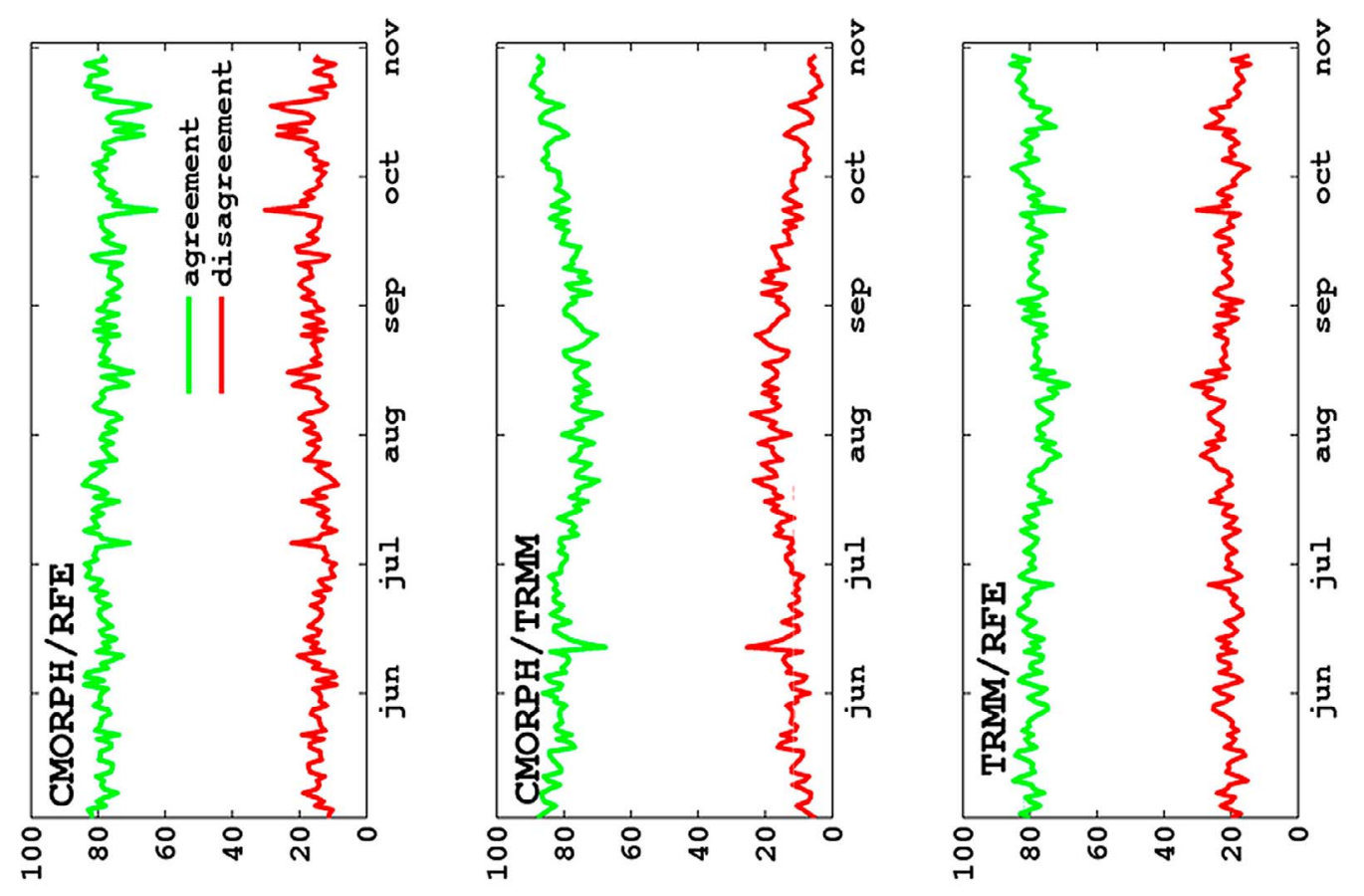

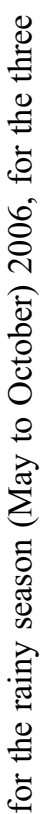
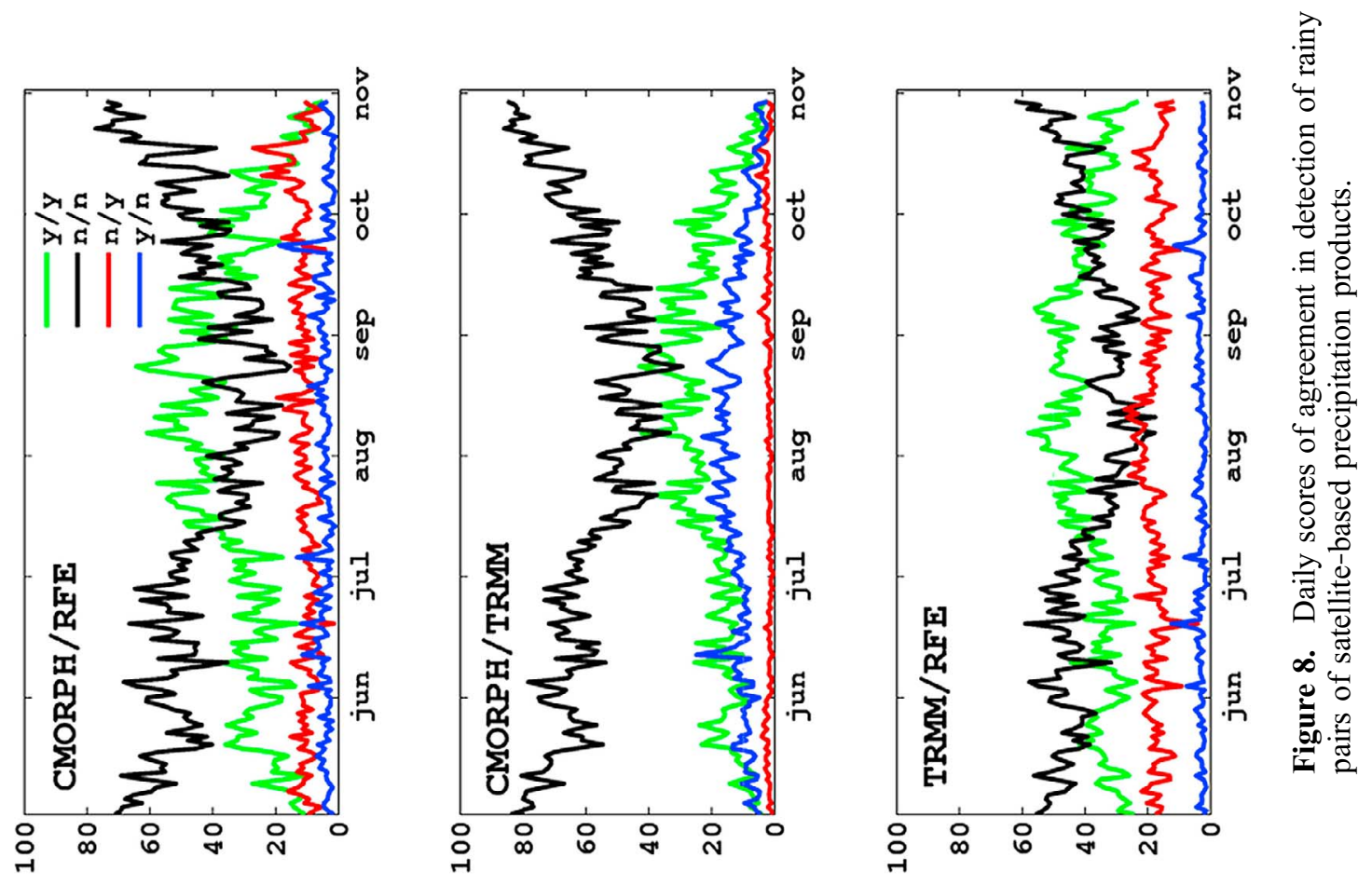
Table 4. Statistical Values of the Linear Regressions Between Satellite-Based Precipitation Products for Precipitation Amounts for the Rainy Seasons (May to October) 2004-2007 and Over the Area $10^{\circ} \mathrm{N}-20^{\circ} \mathrm{N} ; 20^{\circ} \mathrm{W}-35^{\circ} \mathrm{E}$

\begin{tabular}{lcccc}
\hline & Slope & $\begin{array}{c}\text { Intercept } \\
(\mathrm{mm})\end{array}$ & $\begin{array}{c}\text { Squared } \\
\text { Correlation }\end{array}$ & $\begin{array}{c}\text { Mean Absolute } \\
\text { Error }(\mathrm{mm})\end{array}$ \\
\hline CMORPH/RFE2.0 & 1.48 & 4.3 & 0.65 & 17.8 \\
CMORPH/TRMM3B42 & 0.99 & 13.1 & 0.43 & 21.4 \\
TRMM3B42/RFE2.0 & 0.78 & 5.6 & 0.41 & 13.7 \\
\hline
\end{tabular}

disagreement ( $\mathrm{y} / \mathrm{n}$ and $\mathrm{n} / \mathrm{y})$ are computed for each day of each year over the whole area. The results obtained for year 2006 are displayed in Figure 8.

[43] The temporal evolutions of these scores differs from one couple of rainfall products to the other. For each couple, the agreement on rainy days increases from the beginning to the middle of the rainy season and then decreases. Total precipitation exhibits the same pattern [see e.g., Lebel and Ali, 2009] suggesting a coinciding increase of the frequency and intensity of the precipitation, in agreement with the observations of Dai et al. [2007]. On the other hand, the agreement score on nonrainy days is obviously the minimum at the maximum of the rainy season and the maximum at the beginning and at the end of the rainy season, where nonrainy days are the most frequent cases. The total agreement scores are stable during the whole period for the couple CMORPH/RFE2.0, but exhibit a slight seasonal trend for the pairs involving the TRMM3B42 product, suggesting a seasonal bias in the detection of rainy days for this product.

[44] For the CMORPH/RFE2.0 couple, the two scores corresponding to disagreement $(\mathrm{y} / \mathrm{n}$ and $\mathrm{n} / \mathrm{y})$ have comparable values and temporal patterns. The scores for the pairs involving TRMM3B42 differ significantly, underlining, as noticed previously, that the TRMM3B42 product detects less rainy days than the CMORPH and RFE2.0 products. The same features are noticed for the other years of the studied period (not shown).

[45] A similar day-by-day analysis in terms of dry spells yields similar conclusions (not shown): the mean dry spell duration is longer at the beginning and at the end of the rainy season, and it reaches a minimum at its core. This mean duration is slightly greater for CMORPH since the dry spells computation for this product includes more cells (that meet the germination criterion) at the northern edge of the area of interest, which shows low rainfall and very strong intermittency.

4.2.2. Conclusion on Rainfall Frequency and Dry Spells

[46] A satisfying global agreement between the different satellite-based precipitation products was found for the daily rain detection and dry spell analysis, especially in areas where rainfall is either very weak or very strong. A weakest, but still very good agreement is also observed in areas exhibiting intermediate rainfall patterns, i.e., in the Sahelian area stricto sensu (100 to $600 \mathrm{~mm}$, i.e., approximately between $14^{\circ} \mathrm{N}$ and $16^{\circ} \mathrm{N}$, see section 1). This underlines the need to focus analysis on the specific criterion of rainfall daily frequency. Moreover, this good level of agreement persists all through the rainy season. For the TRMM3B42 product, the comparison with the other satellite-based precipitation products suggests a seasonal bias in the detection of the rainy days, and a slightly different spatial distribution of dry spells. As a general trend, the rainfall frequency is the highest with the RFE2.0 product and the lowest with the TRMM3B42 product.

\subsection{Rainfall Amounts}

[47] The consistency of the precipitation amounts is examined for the different satellite-based precipitation products. First, a direct comparison is performed over the whole Sahel and over the CILSS countries area; second, the spatial distribution of the rainfall differences between products is examined; finally, the temporal evolution of the agreement between products is evaluated.

4.3.1. Satellite Products

\subsubsection{Ten-Day Precipitation Amounts}

[48] Direct comparisons of 10 day precipitation amounts from a couple of satellite-based precipitation products are performed at a spatial resolution of $0.5^{\circ}(\mathrm{n} \sim 100,000)$ over the whole Sahel $\left(10^{\circ} \mathrm{N}-20^{\circ} \mathrm{N}, 20^{\circ} \mathrm{W}-35^{\circ} \mathrm{E}\right.$, values over oceans being removed) for the four rainy seasons of the period 2004-2007 (Table 4).

[49] Overall, the agreement between the three satellitebased products is good: the correlation coefficients range between 0.41 and 0.65 , and the slopes of the linear regression range from 1.48 to 0.78 . The slope of the linear relationships between the CMORPH and RFE2.0 products is the highest (1.48) and is associated with the slowest intercept $(4.3 \mathrm{~mm})$ and a medium mean absolute error $(17.8 \mathrm{~mm})$. The squared correlation is the highest with about 0.65 (meaning that $65 \%$ of the variability of the data is explained by the linear regression). The slope of the linear relationship between the TRMM3B42 and CMORPH products is very close to 1, but the intercept and the mean absolute error are the highest (13.1 $\mathrm{mm}$ and $21.4 \mathrm{~mm}$, respectively), suggesting a small systematic bias between these two products. The correlation coefficient is lower (0.43) and close to the 1 obtained for the TRMM3B42/RFE2.0 couple (0.41). The linear regression between TRMM3B42 and RFE2.0 gives a slope of 0.8 , without significant systematic bias (intercept $\sim 5.56 \mathrm{~mm}$ ). Moreover the mean absolute error is the lowest with $13.66 \mathrm{~mm}$. 4.3.1.2. Spatial Distribution of Precipitation Amounts

[50] The differences between the different satellite-based precipitation products in terms of precipitation amounts over the four rainy seasons 2004-2007 are displayed in Figure 9. The highest differences in precipitation amounts involve the CMORPH product. The regions where the differences are the highest are located along the Guinean coast $\left(15^{\circ} \mathrm{W}-\right.$ $10^{\circ} \mathrm{W}, 10^{\circ} \mathrm{N}$ ) and in the southern part of the area, i.e., in the areas where precipitation is the highest. These areas almost perfectly match the maximum of relative precipitation of the CMORPH product. This clearly shows that the precipitation amounts derived from CMORPH are much higher than those from the two other products. In contrast, the areas where the differences are minimum are located at the northern edge of the studied area where rainfall is extremely weak.

[51] The two satellite-based precipitation products using rain gauge data for adjusting their precipitation rates retrievals, i.e., TRMM3B42 and RFE2.0, are in good agreement over most of the area. The differences are less than $100 \mathrm{~mm}$ in mean annual absolute value for $47 \%, 47 \%$, and $87 \%$ of the studied area for CMORPH-RFE2.0, CMORPH-TRMM3B42, and TRMM3B42-RFE2.0, respectively. Higher differences are 

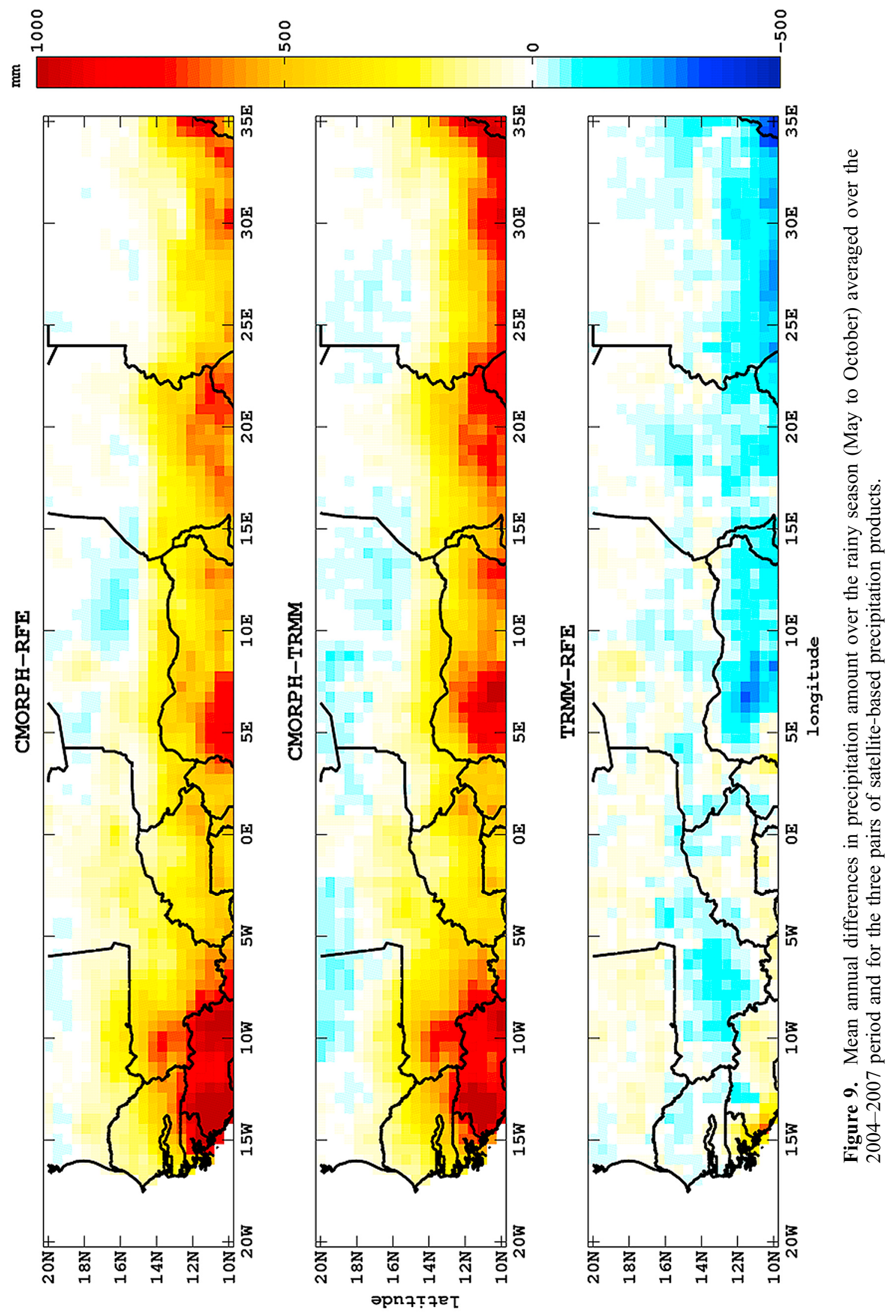
Table 5. Statistical Values of the Linear Regressions Between Satellite-Based Precipitation Products and Kriged Rain Gauge Data for Precipitation Amounts for the Rainy Seasons (May to October) $2004-2007$ and Over the Area $10^{\circ} \mathrm{N}-17.5^{\circ} \mathrm{N} ; 17.5^{\circ} \mathrm{W}-$ $22.5^{\circ} \mathrm{E}$

\begin{tabular}{lcccc}
\hline & Slope & $\begin{array}{c}\text { Intercept } \\
(\mathrm{mm})\end{array}$ & $\begin{array}{c}\text { Squared } \\
\text { Correlation }\end{array}$ & $\begin{array}{c}\text { Mean Absolute } \\
\text { Error }(\mathrm{mm})\end{array}$ \\
\hline CMORPH & 1.34 & 8.0 & 0.60 & 22.2 \\
RFE2.0 & 0.77 & 5.0 & 0.69 & 10.1 \\
TRMM3B42 & 0.94 & 2.2 & 0.60 & 12.0 \\
\hline
\end{tabular}

observed in a zone located in Sudan $\left(25^{\circ} \mathrm{E}-35^{\circ} \mathrm{E}, 10^{\circ} \mathrm{N}-12^{\circ} \mathrm{N}\right)$ for which the precipitation derived from TRMM3B42 is significantly lower than that derived from RFE2.0.

[52] As indicated in section 4.2, the frequency of rain days detected is intermediate between the two other products for the CMORPH product. This strongly suggests that the large differences observed in the precipitation amount retrieved by CMORPH and those provided by the two other satellite-based precipitation products result from a large "overestimation" of the daily precipitation rates for rainy days similarly detected by the other products. This overestimation of the rainfall amounts by CMORPH had already been noticed by Jobard et al. [2011] for the June-September 2004-2006 period and by Dai et al. [2007] at a global scale.

\subsubsection{Ten-Day Variability}

[53] In order to evaluate the consistency between the different satellite-based precipitation products through time, the slopes of the linear regressions have been computed every 10-day period from May to October over the 4 yearperiod over the Sahel region. These slopes show a systematic trend: rainfall amounts derived from the RFE2.0 product are lower than those derived from TRMM3B42 (slope between 0.4 and 1) except at the very beginning and at the end of the rainy season (when the slope can reach $\sim 1.2$ ). RFE2.0 and TRMM3B42 values are much lower than those derived from CMORPH (slope from 0.2 to 0.8 ). The slopes, averaged over the rainy seasons are quite stable with standard deviations of the order of $\sim 10 \%$. However, they can strongly vary as a function of the year for the same decade, with standard deviations up to $40 \%$.

\subsubsection{Comparison with Kriged Rain Gauge Data 4.3.2.1. Decadal Precipitation Amounts}

[54] The precipitation amounts at $0.5^{\circ}$ spatial resolution derived from the satellite products are cumulated by 10 day period to be compared with the 10-days precipitation amounts from the kriged rain gauge data (Table 5, $\mathrm{n} \sim 80000$ ).

[55] The comparison of the 10 day precipitation amounts shows a good agreement between satellite-based estimates and kriged data: the squared correlation coefficients range between 0.6 and 0.7. These values are similar to those obtained by Jobard et al. [2011], but the number of values compared here is much higher; our period of interest is longer and our area is wider. The slopes of the linear regressions range between 0.77 and 1.34, and the intercepts are low (between $2.2 \mathrm{~mm}$ and $8 \mathrm{~mm}$ ). The level of agreement is thus noticeably better than the agreement observed between satellite products, and compares well with the values obtained by Roca et al. [2010] on two 10-day periods (11-20 June 2006 and 1-10 August 2006), taking into account estimation errors (squared correlations about 0.9 , slopes about 0.8 to 1.3 ).

[56] If the kriged data are considered as a reference in terms of precipitation amounts, these results indicate that CMORPH overestimates precipitation amounts by about $34 \%$, with a much larger systematic bias than the other products as reflected by the highest intercept $(\sim 8 \mathrm{~mm})$ and mean absolute error $(22.2 \mathrm{~mm})$. On the other hand, RFE2.0 tends to underestimate precipitation rates by $23 \%$, with a lower bias (intercept $\sim 5 \mathrm{~mm}$ ) than CMORPH and the lowest mean absolute error $(\sim 10 \mathrm{~mm})$. Moreover, RFE2.0 shows the highest squared correlation, with more than $69 \%$ of the variability of the values explained by the linear regression. TRMM3B42 exhibits the slope the closest to $1(0.94)$ and the lower intercept $(\sim 2 \mathrm{~mm})$, suggesting a better agreement with the kriged rain gauge data in terms of precipitation rates. However, its squared correlation is 0.6 , i.e., approximately equal to that of the CMORPH product.

\subsubsection{Spatial Distribution}

[57] The differences in precipitation amounts between the satellite-based precipitation products minus the kriged rain gauge data are computed for the four rainy seasons (Figure 10). The largest differences are again located along the Guinean coast $\left(13^{\circ} \mathrm{W}, 10^{\circ} \mathrm{N}\right)$, and the lowest ones, for the RFE2.0 and TRMM3B42 products, are located in an intermediate strip, approximately between $13^{\circ} \mathrm{N}$ and $15^{\circ} \mathrm{N}$. The differences are positive between the CMORPH data and the kriged rain gauge data, indicating much stronger precipitation amounts from the satellite-based data. The RFE2.0 and TRMM3B42 products are both in satisfying agreement with the kriged rain gauge data over most of the area with absolute differences lower than $100 \mathrm{~mm}$ over $78 \%$ and $76 \%$, respectively, of the surface, but for only $27 \%$ for CMORPH. The kriged rain gauge data are generally slightly lower than the satellite products in the areas where high rainfall is observed (central and southern) and slightly greater on the northern borders, where rainfall is the weakest. The underestimation of satellite-based products with respect to kriged data for low rainfall amounts can be partly explained by the underestimation of the frequency of small rainfall linked to high spatial intermittency [Ali et al., 2005b].

\subsubsection{Ten-Day Variability}

[58] The slopes of the linear regressions of precipitation amounts every 10 day period between satellite-based precipitation products and kriged rain gauge data (not shown) confirm the differences previously noted between the three satellite products. The slopes between satellite products and kriged data are higher at the beginning and at the end of the rainy seasons, while they are minimum, and generally closer to 1 , in the middle of the rainy season. This better agreement with kriged data at the core of the rainy season was also observed for other satellite-based rainfall products [Ali et al., 2005b]. For the CMORPH product, they largely exceed 1 both at the beginning and at the end of the rainy season, while they range between 1 and 2 between July and September. This indicates that the precipitation amounts are overestimated by CMORPH during the whole rainy season, but less toward the middle of the wet season. Moreover, the interannual variability observed is the strongest with the CMORPH product. The slopes of the regressions with 


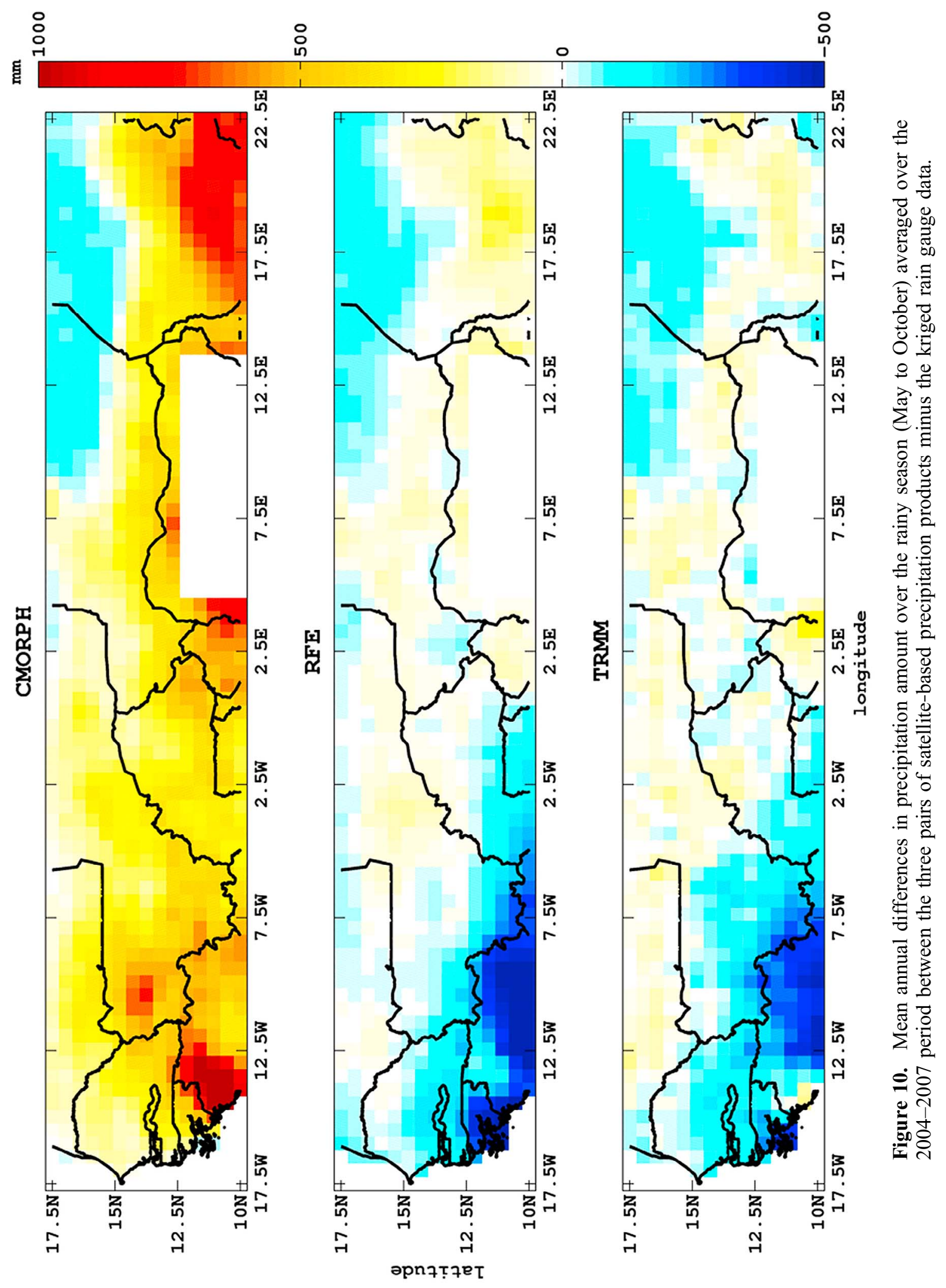


Table 6. Inputs Required by the STEP Model: Parameters, Variables, Symbols, Sources and Units, and Reference Values (Minimum and Maximum Values) for Parameters

\begin{tabular}{|c|c|c|c|}
\hline Parameter or Variable & Symbol & Source & $\begin{array}{l}\text { Unit and Reference Value } \\
\text { (Minimum and Maximum) }\end{array}$ \\
\hline Maximum conversion efficiency & $\varepsilon_{\mathrm{c}}$ & $\begin{array}{l}\text { Mougin et al. }[1995] \\
\text { Tracol et al. }[2006]\end{array}$ & $5 \mathrm{~g} / \mathrm{MJ}(2.5-7)$ \\
\hline Initial biomass & $\mathrm{B}_{\mathrm{g}} 0$ & $\begin{array}{c}\text { Mougin et al. }[1995] \\
\text { Tracol et al. }[2006]\end{array}$ & $1 \mathrm{~g} / \mathrm{m}^{2}(0.5-2.5)$ \\
\hline Proportion of C3-plants & $\mathrm{C} 3$ & Cornet [1981], Hiernaux et al. [2009], Jarlan et al. [2008] & $43 \%(30-60)$ \\
\hline Proportion of C4-plants & $\mathrm{C} 4$ & Cornet [1981], Hiernaux et al. [2009], Jarlan et al. [2008] & $57 \%(40-70)$ \\
\hline Initial Specific Leaf Area & $\mathrm{SLA}_{\mathrm{g}} 0$ & Jarlan et al. $[2008]$ & $200 \mathrm{~cm}^{2} / \mathrm{g}(180-280)$ \\
\hline Albedo & & MODIS & \\
\hline Daily min. temperature & & ECMWF & ${ }^{\circ} \mathrm{C}$ \\
\hline Daily max. temperature & & ECMWF & ${ }^{\circ} \mathrm{C}$ \\
\hline Solar radiation & & ECMWF & $\mathrm{W} / \mathrm{m}^{2}$ \\
\hline
\end{tabular}

RFE2.0 and TRMM3B42 are significantly closer to 1 , even if they also decrease in the middle of the wet season to reach values of the order of 0.5 . This suggests that these two satellite products could underestimate precipitation amounts during a period of high rainfall. It can be noticed that the values for 11-20 June 2006 and 1-10 August 2006 for the TRMM3B42 product compare very well with the values obtained by Roca et al. [2010] (slopes of 0.83 and 1.29, respectively).

[59] The three satellite-based rainfall products studied here show similar field structure and daily frequency over the Sahel. Those characteristics are also in good agreement with the 10-day kriged rain gauge data over the Sahel. However, the CMORPH product tends to overestimate rainfall amount over the Sahelian belt. In the following section, we will discuss the influence of the use of these different rainfall fields on the Sahelian vegetation modeling.

\section{Vegetation Modeling}

[60] Simulations of seasonal variations of the Sahel vegetation have been performed with the STEP model [Mougin et al., 1995]. This model has been specifically designed to simulate, at a daily time scale, the growth of the Sahel annual herbaceous by describing explicitly the physical and biological processes associated to plant growth (photosynthesis, respiration, senescence, and litter production) and water budget (evaporation, transpiration, and water fluxes in the soil). The modeled vegetation consists of an herbaceous layer composed of annual species. From the simulated biomass, vegetation structural parameters such as Leaf Area Index (LAI), Vegetation Cover Fraction, and vegetation height are estimated, allowing comparisons with satellite or field measurements [e.g., Lo Seen et al., 1995; Tracol et al., 2006]. The main required input data sets are daily meteorological data (air temperature, global radiation, and rainfall) and soil characteristics (texture with depth, albedo), input parameters being the initial green biomass $\left(\mathrm{B}_{\mathrm{g} 0}\right)$, the $\mathrm{C} 3 / \mathrm{C} 4-$ plants proportion, the maximum conversion efficiency $\left(\varepsilon_{\mathrm{c}}\right)$, and the Specific Leaf Area at emergence $\left(\mathrm{SLA}_{0}\right)$ (see Table 6).

5.1. Implementation of the STEP Model at the Regional Scale

[61] The STEP model [Mougin et al., 1995] is a onedimensional model that has been designed to run on well- documented sites. The aim here is to perform vegetation simulations over the whole area of interest, i.e., to determine the values of the different input variables and parameters. In that regard, the strategy depends on the model sensitivity to these inputs. The most determinant input variables are first, daily rainfall, and second, solar radiation, yet solar radiations seldom limit vegetation photosynthesis in the Sahel environment, contrary to rainfall.

5.1.1. Calibration Parameters

[62] According to several previous studies dealing with the STEP model [e.g., Jarlan et al., 2005, 2008; Mangiarotti et al., 2008], the most sensitive parameters are the maximum conversion efficiency $\varepsilon_{\mathrm{c}}$, the initial green biomass $\mathrm{B}_{\mathrm{g} 0}$, the C3/C4-plants proportion, and the Specific Leaf Area at emergence $\mathrm{SLA}_{0}$. A thorough description of these parameters can be found in the article by Mougin et al. [1995]. The C3/C4-plant proportions and $\mathrm{SLA}_{0}$ are difficult to evaluate at a regional scale. Default values obtained from 25 years of ground measurements over the AMMA-CATCH site in Mali [Tracol et al., 2006; Hiernaux et al., 2009; Mougin et al., 2009a] are considered here, and in consequence, the simulations are performed on an area restricted in latitude $\left(12^{\circ} \mathrm{N}-20^{\circ} \mathrm{N}, 20^{\circ} \mathrm{W}-35^{\circ} \mathrm{E}\right)$ to match with the appropriate type of vegetation. The two other calibration parameters, $\mathrm{B}_{\mathrm{g} 0}$ and $\varepsilon_{\mathrm{c}}$, are determined using satellite observation products as reference. The LAI designates the one-sided leaf surface per soil unit surface (in $\mathrm{m}^{2} / \mathrm{m}^{2}$ ). The Moderate Resolution Imaging Spectroradiometer (MODIS) LAI product [Myneni et al., 2002] - onboard the TERRA and AQUA platforms - is retained for its fine resolution $(\sim 1 \mathrm{~km}$, 8 days) and its good skills over Sahel [Fensholt et al., 2004; Mougin et al., 2009b], except an offset of about $0.2 \mathrm{~m}^{2} / \mathrm{m}^{2}$ during the dry season.

[63] Using both the MODIS LAI data ( $\mathrm{LAI}_{\text {MODIS }}$ ) as a reference and typical values of SLA for Sahelian grass species [Jarlan et al., 2008], the initial biomass is estimated as follows: $\mathrm{B}_{\mathrm{g} 0}=\mathrm{LAI}_{\mathrm{MODIS}} / \mathrm{SLA}$. From this, regional simulations have been performed and values for the $\varepsilon_{\mathrm{c}}$ parameter have been determined by minimizing the difference between simulations and MODIS LAI data in four zones. These zones were defined for their contrasted behaviors in terms of absolute differences with respect to MODIS LAI values. The obtained values range between 3.0 and $6.0 \mathrm{~g} / \mathrm{MJ}$, which are in agreement with previous studies [e.g., Mougin et al., 1995; Tracol et al., 2006]. 


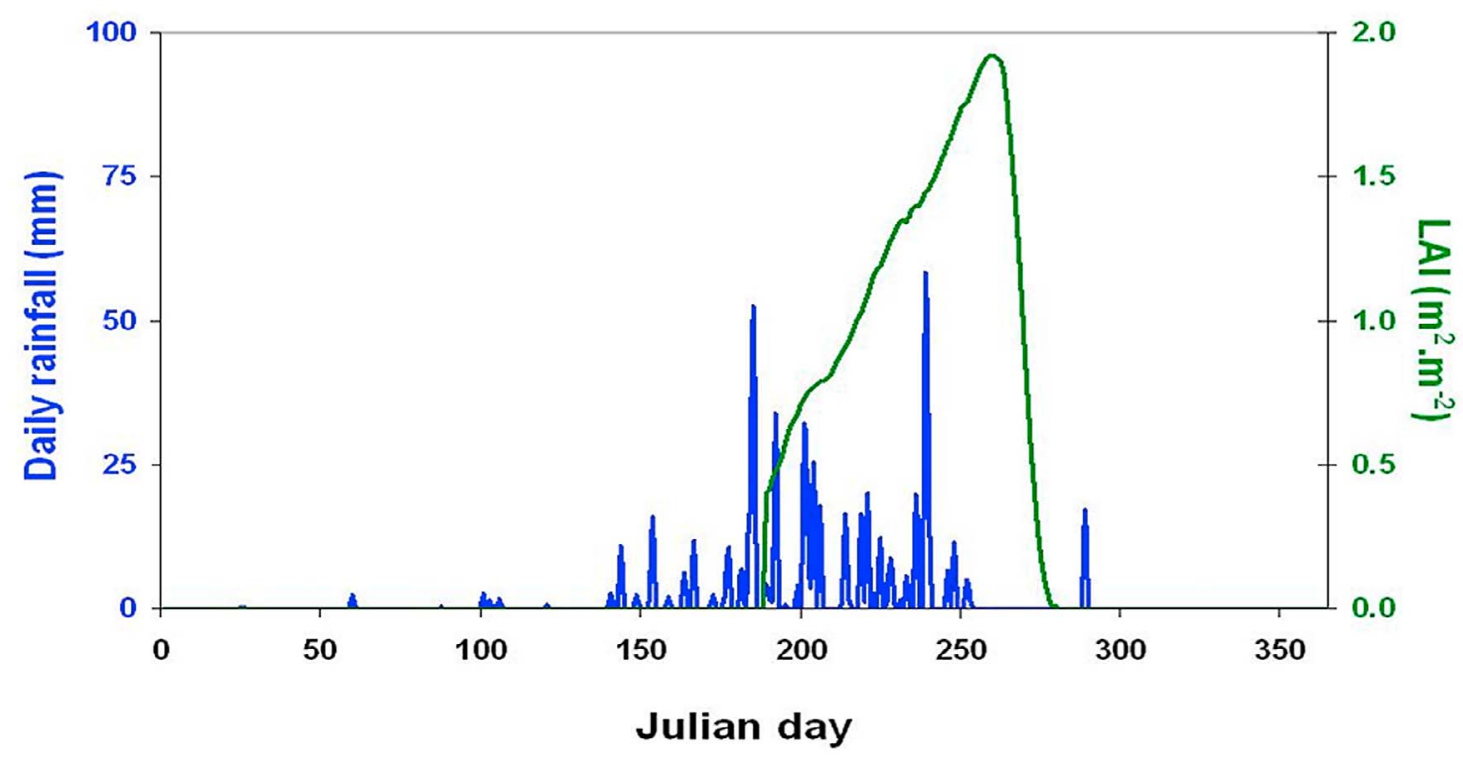

Figure 11. A simulated green biomass dynamics through the year 2004 by the STEP model with TRMM3B42 rainfall data sets.

\subsubsection{Meteorological Data and Soil Characteristics}

[64] As mentioned in section 1, the objective is to evaluate different rainfall products as inputs in regional vegetation modeling. Thus, the three satellite-based rainfall products were successively used as inputs to perform vegetation simulations using the STEP model. The other meteorological parameters are operational data from the European Center for Medium Range Weather Forecast (ECMWF). Soil texture profiles are adapted from the Harmonized World Soil Database (HWSD) [FAO/IIASA/ISRIC/ISS-CAS/JRC, 2009], which is the finest available soil database. Its resolution is $\sim 1 \mathrm{~km}$, but data were aggregated at the $0.1^{\circ}$ or $0.25^{\circ}$, depending on the rainfall product used. Surface albedo is the product provided by the MODIS database.

\subsection{Vegetation Simulations and Comparisons to MODIS Observations}

\subsubsection{Vegetation Dynamics}

[65] The seasonal dynamics of the green biomass is simulated for the year 2004 by using TRMM3B42 rainfall data (Figure 11). No green vegetation is simulated during the dry season until approximately beginning of July (day of year (DOY) 180). As simulated by the STEP model, annual vegetation starts growing as soon as the humidity of the soil is greater than the wilting point during 5 consecutive days. The plant growth lasts until approximately early September (DOY 250) matching with the biomass maximum and the fructification stage. Finally, the senescence takes place from the maximum of biomass to end of October (DOY 280).

[66] The sensitivity of the simulations to the use of the different satellite-based rainfall products is evaluated by examining the main features of the vegetation dynamics over years 2004 to 2007: the location of the northern limit of the vegetated area, the date of beginning of the plant growth $\left(\mathrm{T}_{0}\right)$, the date of biomass maximum, and the LAI values at $\mathrm{T}_{0}+15$ days and at maximum.

[67] In the context of the strong latitudinal rainfall gradient in Sahel, the latitudinal location of the northern limit of annual vegetation growth is an important issue in estimating the regional agreement between simulated and observed seasonal vegetation. More precisely, the following comparison aims at checking whether the modeled vegetation is spatially and temporally consistent at the regional scale with the satellite observations. The grid cells for which the northern limit of the vegetated area is detected are reported according to their latitude as obtained from STEP simulations versus their latitude as obtained from MODIS observations (Figure 12). Their cumulated frequency across longitude over the whole area of interest is indicated through a color scale. The graphs illustrate the cumulated results over years 2004 to 2007 for the first day of each month from May to October (growing season) and separately for each satellite-based rainfall product used as rainfall inputs in the STEP model. The correlation coefficient between latitude of the northern limit of simulated and observed vegetation is also indicated on each panel. The grid cells are smaller and more numerous for the RFE2.0 product as its resolution is 0.1 . A perfect agreement between observations and simulations would correspond to all grid cells aligned on the 1:1 line.

[68] On the whole, seasonal vegetation is not well developed before July, and the agreement between simulations and observations is poor until this date. The best agreement is observed for 1 August and 1 September, whatever the rainfall product, that is in the middle of the growing season when vegetation density is at maximum. A poor agreement is also observed for 1 October, corresponding to the senescence stage. This observation can be done for the three rainfall products suggesting that the STEP model does not simulate this last vegetation stage well. Moreover, the northern limit ofthe vegetated area is located further south by the model in comparison with satellite observations from August to October (the points are located above the 1:1 line). Although these trends are observed for the three satellite-based products, correlation coefficients show some variability. The best agreement (over the whole rainy season) is found when using the CMORPH product as rainfall input, which was 

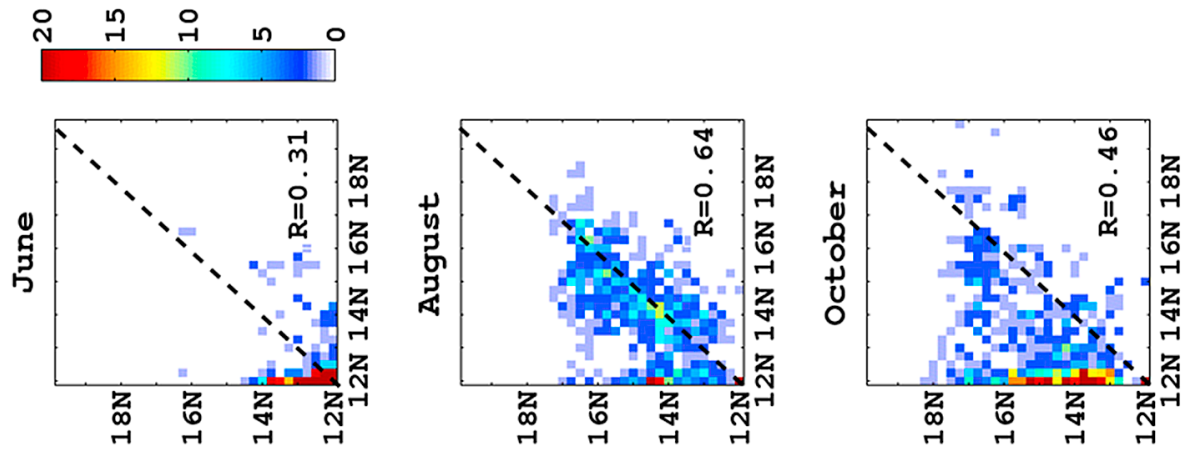

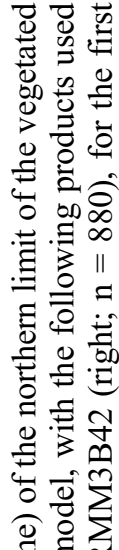
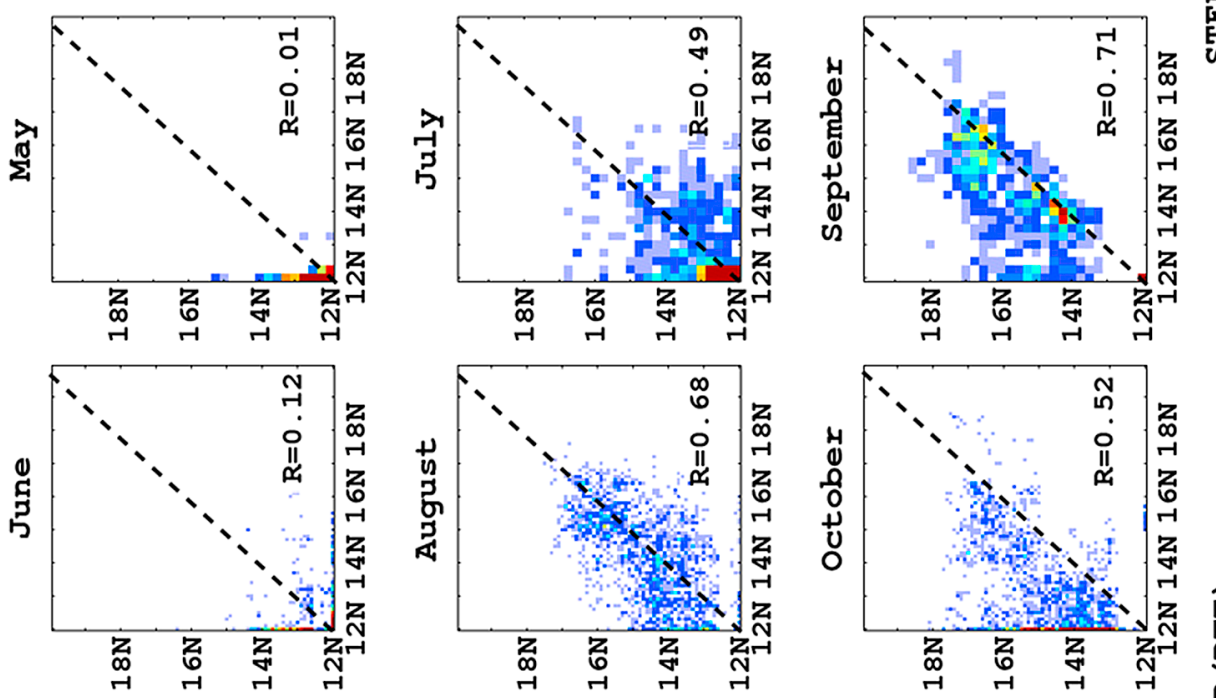

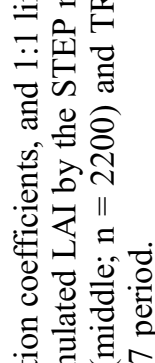
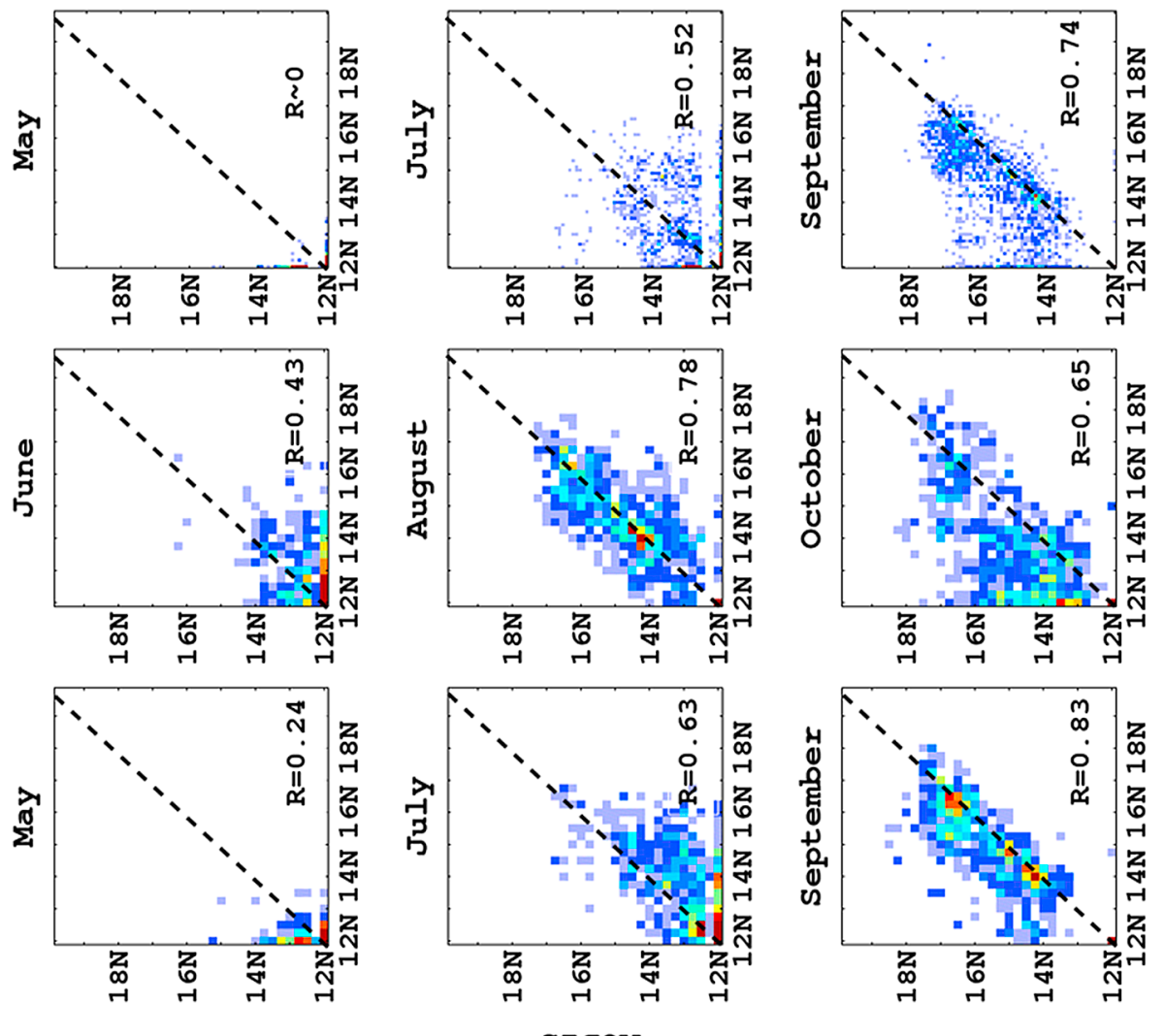

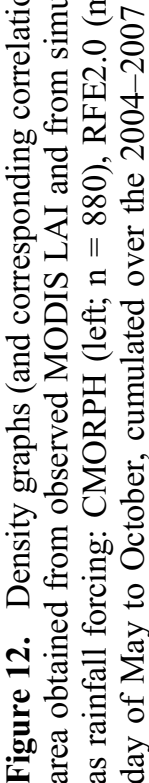


rather unexpected since CMORPH shows the strongest disagreement with kriged gauge rainfall data.

[69] The cumulated distributions of the date of beginning of vegetation growth for the different products are displayed in Figure 13. The distributions for the simulations run with TRMM3B42 and RFE2.0 show a very similar behavior, in good agreement with MODIS observations, with an inflection point at the end of May (around DOY 150), when the vegetation starts to grow over most of the area. The vegetation growth as seen by MODIS starts about 20 days earlier than the modeled values using the satellite estimates. This is mainly because the STEP model prevents vegetation to start growing before 1 May in order to avoid unrealistic starts over the whole Sahelian band. By early September (approximately DOY 250), herbaceous vegetation has started to grow in almost all grid boxes. The simulations run with CMORPH show an earlier onset of the vegetation cycle that concerns a relatively high fraction of the studied area. In other words, vegetation growth begins roughly 5 to 20 days earlier with the CMORPH product than with others. This result is in accordance with the rainfall overestimation of this product with respect to the others. The area covered by the simulated vegetation growth is also slightly larger when using CMORPH precipitation than when using the two other precipitation products (for example, in 2004: 51\% (MODIS), $48 \%$ (CMORPH), 39\% (RFE2.0), and 47\% (TRMM3B42) of the area is covered by vegetation).

[70] The distribution of the date of vegetation maximum is less scattered between products (Figure 14). In the simulations, the main inflection point occurs in early September (around DOY 250), and by the end of October (DOY 300) the whole vegetated area has reached its maximum whatever the satellite-based precipitation products used as input, and for the MODIS observations as well. From a regional point of view, the simulations reach their maximum at a smoother rate than MODIS observations. TRMM3B42 and RFE2.0 products show very similar responses in terms of vegetation simulation, as was expected because of their very similar daily rainfall frequency and amounts.

\subsubsection{Vegetation Amounts}

[71] An illustration of the impact of differences between products on modeled vegetation in terms of dry spells is given by Figure 15, for the year 2004 and the CMORPH and TRMM3B42 products. MODIS maximum LAI are represented on Figure 15a to facilitate the interpretation of these results. The area where TRMM3B42 presents more dry spells lasting 5 days or more than CMORPH appears on Figure 15b (blue color). On Figure 15c, as expected, this corresponds to area where the maximum simulated LAI is larger when using CMORPH than TRMM3B42 (yellow color), and where MODIS maximum LAI shows intermediate values $\left(\sim 1-2 \mathrm{~m}^{2} / \mathrm{m}^{2}\right)$. However, the opposite behavior is observed at the southwest section of the area, where MODIS maximum LAI are 2 to $3 \mathrm{~m}^{2} / \mathrm{m}^{2}$ : more dry spells for CMORPH and a larger maximum simulated LAI. This can be explained by the much higher rainfall amounts of the CMORPH product with respect to TRMM3B42 in this area (see Figure 2 and Table 2).

[72] Statistical values of the linear regression between vegetation simulations and MODIS observations are given at 15 days after growth beginning, $\mathrm{T}_{0}+15$ (Table 7) and at vegetation maximum (Table 8). Simulated values are well correlated with the observed ones at $\mathrm{T}_{0}+15$ : correlation coefficients are about 0.7 whatever the rainfall input source, and slopes are larger than 1, indicating that LAI are overestimated by the STEP model by $40 \%$ to $70 \%$. At vegetation maximum, correlations $(>0.8)$ show a very significant agreement between simulations and satellite observations, and intercepts are low (lower than MODIS offset in the dry season) [see Fensholt et al., 2004]. However, the model underestimates by almost a factor of 2 the MODIS LAI values at vegetation maximum. These results suggest that the vegetative cycle is satisfyingly reproduced by the model (see good correlation coefficients) over the whole Sahelian belt, especially in terms of seasonal dynamics. Yet, the simulated cycle is less marked than the observed one in terms of vegetation amounts.

\subsubsection{Conclusion}

[73] Since the three satellite-based precipitation products have very similar daily precipitation frequencies (see section 4), the large differences in dynamics observed between the simulated vegetation fields are mainly due to the overestimation of rainfall amounts by CMORPH, especially at the beginning of the rainy season. Earlier precipitation from CMORPH allows the simulation of the beginning of the vegetation growth at a period for which the necessary conditions are not yet fulfilled for the other products. When considering LAI values, the correlation coefficients are larger for CMORPH used as rainfall input, but with a wider value departure between simulated and observed LAI. In other words, comparison of vegetation simulations for the different satellite-based product confirms that impacts of rainfall characteristics like amounts or frequencies are not straightforward on the agreement with observed vegetation.

[74] These results can be put in perspective with recent works dealing with hydrological modeling as by Hossain and Huffman [2008] (who intended to build metrics interpretable by hydrologists and algorithm developers at hydrologically relevant scales) and Yong et al. [2010] (who studied the skills and impacts of the use of TRMM3B42RT and TRMM3B42v.6 on hydrological modeling in China). Other recent studies deal also with land-surface modeling using satellite-based rainfall products as by Boone et al. [2010] (comparisons of land-surface models over west Africa using the TRMM3B42 product) and Bock et al. [2010] (computation of large-scale water cycle over West Africa using rainfall from meteorological models). However, the impacts of rainfall estimates variability for modeling show strong specificities depending on the scientific issue under consideration [e.g., Pan et al., 2010].

\section{Conclusion}

[75] Three satellite-based precipitation products $(\mathrm{CMORPH}$, RFE2.0, and TRMM3B42) have been intercompared and tested against interpolated rain gauge measurements over a four rainy season period (2004-2007) to evaluate their ability to retrieve the precipitation characteristics that drive seasonal vegetation growth throughout the Sahel region. The criteria of comparison are defined according to their relevance for vegetation dynamics: spatial structure of the rainfall field, precipitation frequency and dry spell distribution, and precipitation amounts. The time scale used for the satellite product intercomparisons is from 1 to 10 days, 

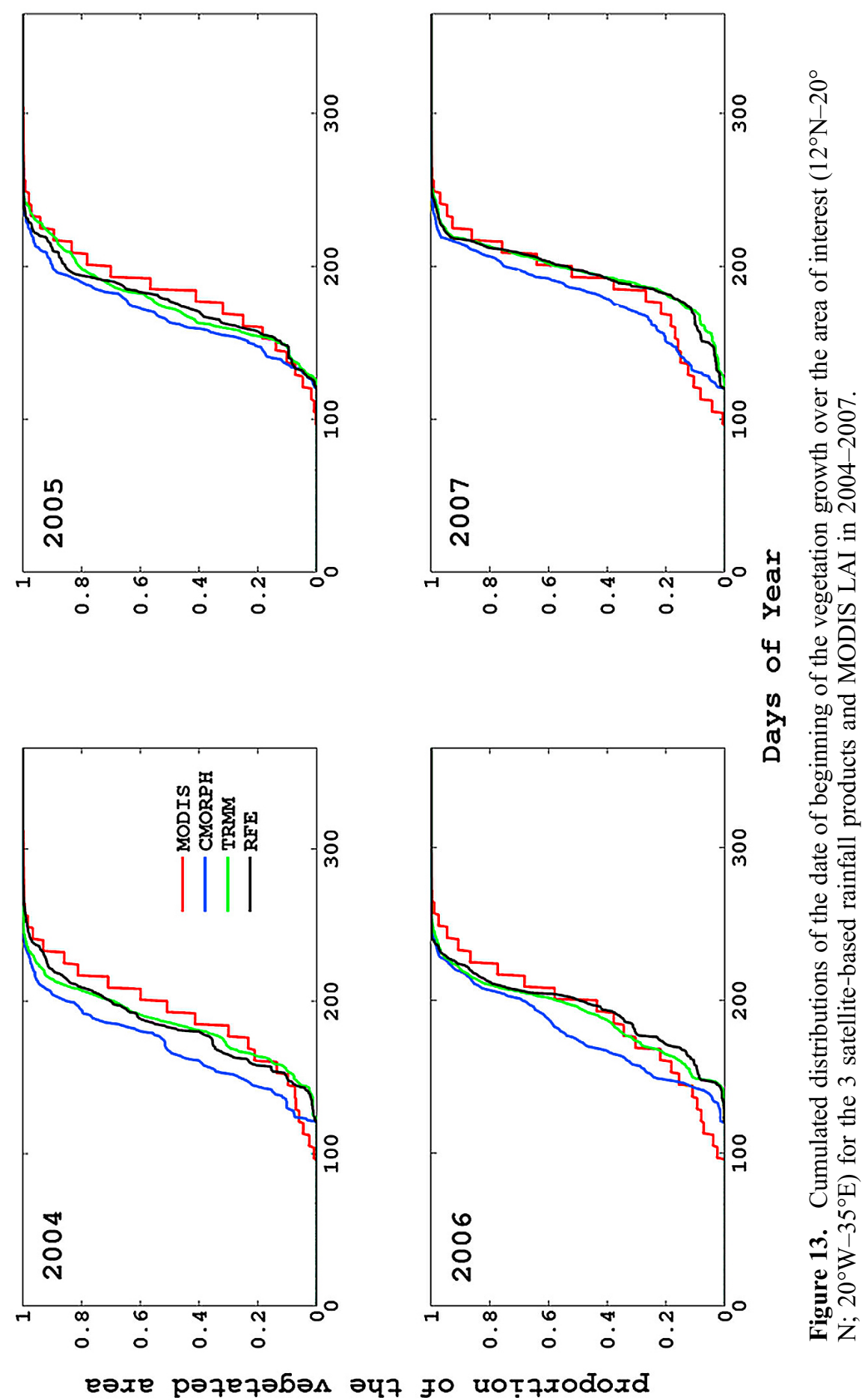

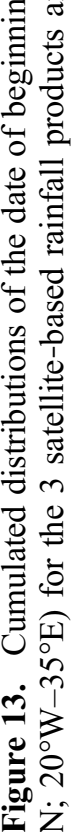

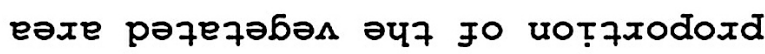



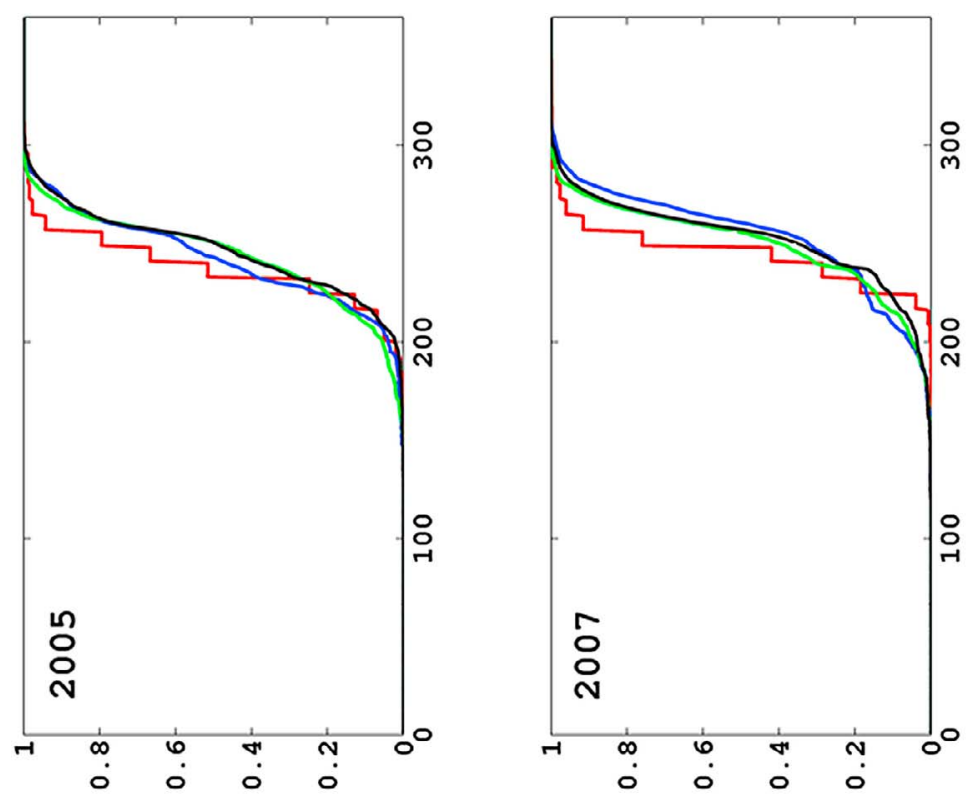

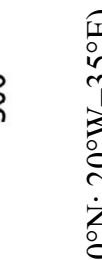
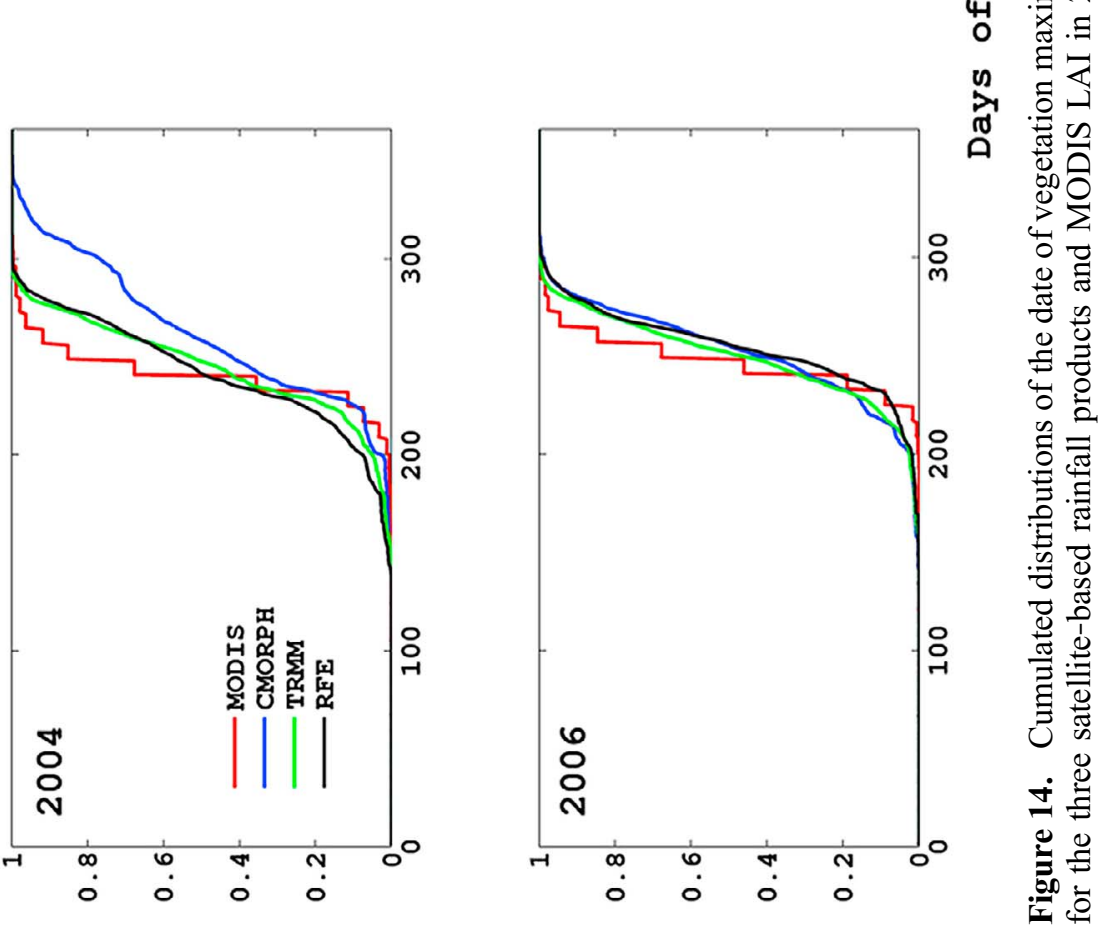

еәте рә7етәбәи әч7 ғо иотฺтодолd 


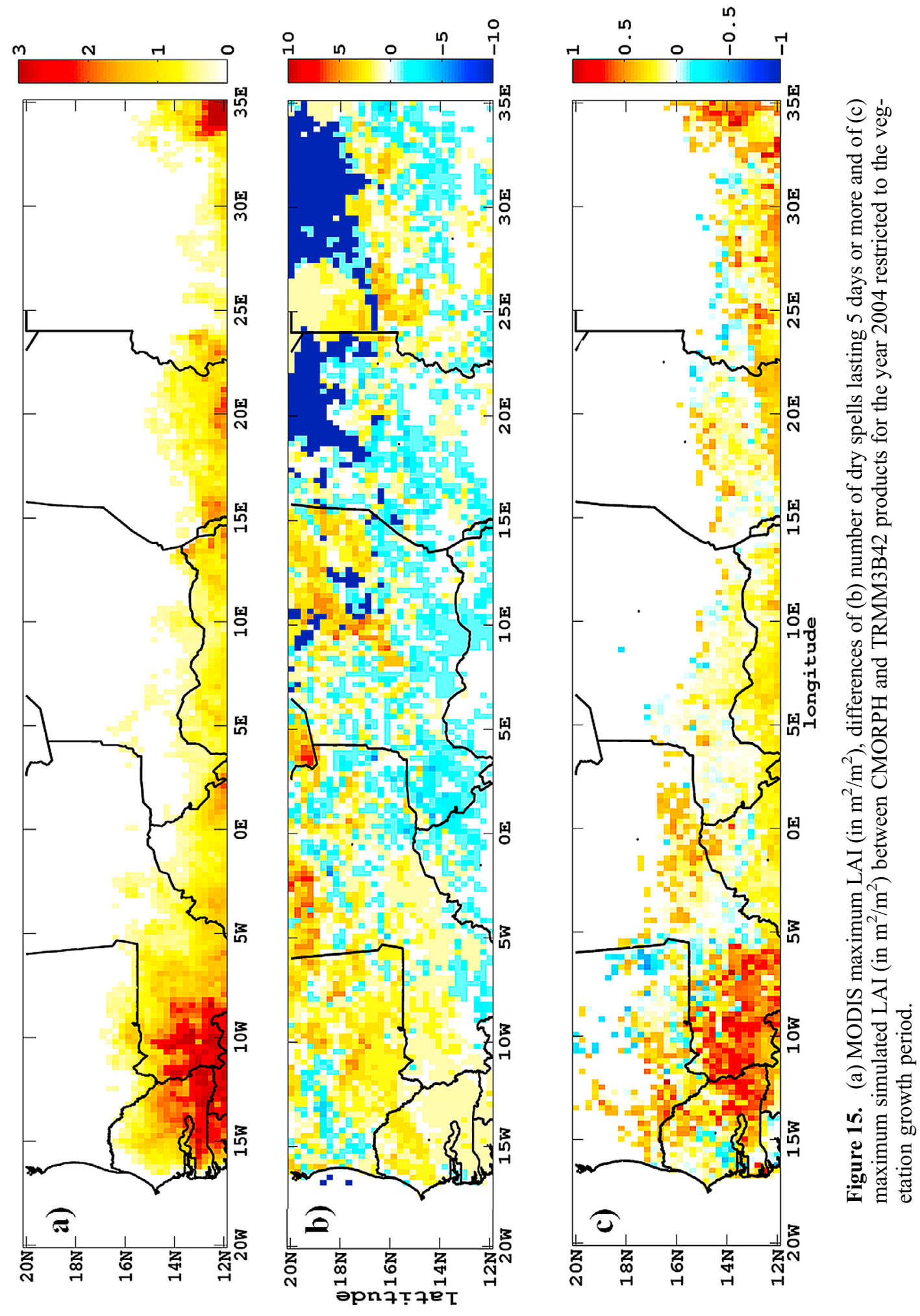


and the spatial resolution is of $0.25^{\circ} \times 0.25^{\circ}$ to $0.5^{\circ} \times 0.5^{\circ}$. Vegetation simulations are performed using a vegetation growth model specifically developed for Sahel over a slightly smaller area, and the simulations are compared with satellite observations (MODIS LAI).

[76] The three selected satellite products are found to be in good agreement over the Sahel region for the three criteria. In terms of spatial structure, the three satellite-based precipitation products are also in a good agreement with the kriged rain gauge data, which is consistent with previous works performed over smaller area or periods [e.g., Roca et al., 2010; Jobard et al., 2011]. Moreover, this agreement is relatively stable through time, from intraseasonal to interannual scales. The three satellite-based precipitation products meet a high agreement (around 80\%) in terms of detection of rainy days. However, the intercomparison of precipitation amounts between the satellite-based precipitation products and the comparison of the satellite products with the kriged rain gauge data clearly indicate that the CMORPH product overestimates rainfall amounts, while both TRMM3B42 and RFE2.0 are in good agreement together and with kriged rain gauge data. When considering vegetation modeling, good agreement is also observed between the dynamics of vegetation growth simulated by STEP using the satellite rainfall products and the satellite observations at a regional scale. This agreement applies to the date of vegetation growth beginning as well as the date of maximum vegetation growth. However, the amounts of vegetation at growth beginning (maximum) are overestimated (underestimated) by the model runs. Differences between satellite rainfall products are retrieved in the model outputs, particularly the earlier start of vegetation growth when using the CMORPH product. Simulations obtained with TRMM3B42 and RFE2.0 have similar behaviors, in good accordance with MODIS observations. This is in agreement with the comparable characteristics of these two products according to our intercomparison criteria.

[77] The good skills of the selected products, although already observed on shorter area or period, are confirmed over the whole Sahelian area on a pluriannual time scale. The specific analysis, focused on the use of these products for vegetation modeling, suggest a new approach and methodology of comparison, and link the results of this comparison to vegetation simulations.

[78] The present work can be considered as a typical example of synergistic research between precipitation estimation missions and surface-vegetation-atmosphere modeling and measurements. Among the current comparable research programs, further scientific investigations could be performed with, for example, the Megha-Tropiques mission or the NASA/JAXA Global mission, and the Soil Moisture and Ocean Salinity (SMOS) space mission.

Table 7. Statistical Values of the Linear Regressions at 15 Days After Vegetation Growth Beginning Between Simulated LAI Using the Three Satellite-Based Products and Observed MODIS LAI, Over the 2004-2007 Period

\begin{tabular}{lccc}
\hline & Slope & Intercept $\left(\mathrm{m}^{2} / \mathrm{m}^{2}\right)$ & Correlation \\
\hline CMORPH & 1.71 & 0.06 & 0.74 \\
RFE2.0 & 1.57 & 0.05 & 0.70 \\
TRMM3B42 & 1.42 & 0.05 & 0.67 \\
\hline
\end{tabular}

Table 8. Statistical Values of the Linear Regressions at Vegetation Maximum Between Simulated LAI using the Three Satellite-Based Products and Observed MODIS LAI, Over the 2004-2007 Period

\begin{tabular}{lccc}
\hline & Slope & Intercept $\left(\mathrm{m}^{2} / \mathrm{m}^{2}\right)$ & Correlation \\
\hline CMORPH & 0.61 & 0.12 & 0.85 \\
RFE2.0 & 0.54 & 0.09 & 0.84 \\
TRMM3B42 & 0.46 & 0.09 & 0.81 \\
\hline
\end{tabular}

[79] Acknowledgments. We would like to thank the AGRHYMET Centre for providing us the 10-day kriged precipitation fields. We also thank M. Gosset, J. Viarre, and P. Hiernaux for their profitable advices and for the reading of this manuscript. Based on a French initiative, AMMA was built by an international scientific group and is currently funded by a large number of agencies, especially from France, UK, USA, and Africa. It has been the beneficiary of a major financial contribution from the European Community's Sixth Framework Research Programme. Detailed information on scientific coordination and funding is available on the AMMA international website: http://www.amma-international.org.

\section{References}

Ali, A., and T. Lebel (2008), The Sahelian standardized rainfall index revisited, Int. J. Climatol., 29, 1705-1714, doi:10.1002/joc.1832.

Ali, A., T. Lebel, and A. Amani (2005a), Estimation of rainfall in the Sahel. Part 1: Error function, J. Appl. Meteorol., 44, 1691-1706, doi:10.1175/ JAM2304.1.

Ali, A., A. Amani, A. Diedhiou, and T. Lebel (2005b), Estimation of rainfall in the Sahel. Part 2: Evaluation of rain gauge networks in the CILSS countries and objective intercomparison of rainfall products, J. Appl. Meteorol., 44, 1707-1722, doi:10.1175/JAM2305.1.

Berges, J. C., F. Chopin, and F. Bessat (2005), Satellite based downscaling algorithm for rainfall estimation, paper presented at the 4th Coloquio Brasileiro de Ciencias Geodesicas, 16-20 May, Curutiba, Brazil. [Available at http://msg.univ-paris1.fr/publi/curitiba.pdf]

Bergès, J. C., I. Jobard, F. Chopin, and R. Roca (2010), EPSAT-SG: A satellite method for precipitation estimation; its concepts and implementation for the AMMA experiment, Ann. Geophys., 28, 289-308, doi:10.5194/angeo-28-289-2010.

Bock, O., F. Guichard, R. Meynadier, S. Gervois, A. Agusti-Panareda, A. Beljaars, A. Boone, M. Nuret, J.-L. Redelsperger and P. Roucou (2010), The large-scale water cycle of the West African monsoon, Atmos. Sci. Lett., 12, 51-57, doi:10.1002/asl.288.

Boone, A. A., I. Poccard-Leclercq, Y. Xue, J. Feng, and P. de Rosnay (2010), Evaluation of the WAMME model surface fluxes using results from the AMMA land-surface model intercomparison project, Clim. Dyn., 35(1), 127-142, doi:10.1007/s00382-009-0653-1.

Cornet, A. (1981), Le bilan hydrique et son rôle dans la production de la strate herbacée de quelques phytocénoses sahéliennes au Sénégal, Ph.D. thesis, 353 pp., Univ. de Montpellier, Montpellier, France.

Dai, A., X. Lin, and K.-L. Hsu (2007), The frequency, intensity, and diurnal cycle of precipitation in surface and satellite observations over low- and mid-latitudes, Clim. Dyn., 29, 727-744, doi:10.1007/s00382-007-0260-y.

Ebert, E. E., J. E. Janowiak, and C. Kidd (2007), Comparison of near-realtime precipitation estimates from satellite observations and numerical models, Bull. Am. Meteorol. Soc., 88, 47-64, doi:10.1175/BAMS-88-1-47.

FAO/IIASA/ISRIC/ISS-CAS/JRC (2009), Harmonized World Soil Database, Version 1.1, http://www.iiasa.ac.at/Research/LUC/ExternalWorld-soil-database/HTML/, Food and Agric. Org., Rome.

Fensholt, R., I. Sandholt, and M. Schultz Rasmussen (2004), Evaluation of MODIS LAI, fAPAR and the relation between fAPAR and NDVI in a semi-arid environment using in situ measurements, Remote Sens. Environ., 91, 490-507, doi:10.1016/j.rse.2004.04.009.

Frappart, F., P. Hiernaux, F. Guichard, E. Mougin, L. Kergoat, M. Arjounin, F. Lavenu, M. Koité, J.-E. Paturel, and T. Lebel (2009), Rainfall regime across the Sahel band in the Gourma region, Mali, J. Hydrol., 375, 128-142, doi:10.1016/j.jhydrol.2009.03.007.

Gebremichael, M., and W. F. Krajewski (2004), Characterization of the temporal sampling error in space-time-averaged rainfall estimates from satellites, J. Geophys. Res., 109, D11110, doi:10.1029/2004JD004509.

Gebremichael, M., and W. F. Krajewski (2005), Modeling distribution of temporal sampling errors in area-time-averaged rainfall estimates, Atmos. Res., 73, 243-259, doi:10.1016/j.atmosres.2004.11.004.

Hiernaux, P., and H. N. Le Houérou (2006), Les parcours du Sahel, Sécheresse, $17,51-71$. 
Hiernaux, P., E. Mougin, L. Diarra, N. Soumaguel, F. Lavenu, Y. Tracol, and M. Diawara (2009), Sahelian rangeland response to changes in rainfall over two decades in the Gourma region, Mali, J. Hydrol., 375, 114-127, doi:10.1016/j.jhydrol.2008.11.005.

Hossain, F., and G. J. Huffman (2008), Investigating error metrics for satellite rainfall data at hydrologically relevant scales, J. Hydrometeorol., 9 563-575, doi:10.1175/2007JHM925.1.

Hsu, K.-L., X. Gao, S. Sorooshian, and H. V. Gupta (1997), Precipitation estimation from remotely sensed information using artificial neural networks, J. Appl. Meteorol., 36, 1176-1190, doi:10.1175/1520-0450 (1997)036<1176:PEFRSI >2.0.CO;2.

Huffman, G. J., R. F. Adler, M. M. Morissey, D. T. Bolvin, S. Curtis, R. Joyce, B. McGavock, and J. Susskind (2001), Global precipitation at onedegree daily resolution from multisatellite observations, J. Hydrometeorol., 2 , 36-50, doi:10.1175/1525-7541(2001)002<0036:GPAODD $>2.0 . C O ; 2$.

Huffman, G. J., R. F. Adler, D. T. Bolvin, G. Gu, E. J. Nelkin, K. P. Bowman, Y. Hong, E. F. Stocker, and D. B. Wolff (2007), The TRMM Multisatellite Precipitation Analysis (TMPA): Quasi-global, multiyear, combined-sensor precipitation estimates at fine scales, J. Hydrometeorol., 8, 38-55, doi:10.1175/JHM560.1.

Jarlan, L., E. Mougin, P. Mazzega, M. Schoenauer, Y. Tracol, and P. Hiernaux (2005), Using coarse remote sensing radar observations to control the trajectory of a simple Sahelian land surface model, Remote Sens. Environ., 94, 269-285, doi:10.1016/j.rse.2004.10.005.

Jarlan, L., S. Mangiarotti, E. Mougin, P. Hiernaux, P. Mazzega, and V. Le Dantec (2008), Assimilation of SPOT/VGT-NDVI data into a Sahelian grassland model, Remote Sens. Environ., 112, 1381-1394, doi:10.1016/j.rse.2007.02.041.

Jobard, I., F. Chopin, J. C. Berges, and R. Roca (2011), An intercomparison of 10-day precipitation satellite products during West African monsoon, Int. J. Remote Sens., 32(9), 2353-2376, doi:10.1080/01431161003698286.

Joyce, R., J. E. Janowiak, P. A. Arkin, and P. Xie (2004), CMORPH: A method that produces global precipitation estimates from passive microwave and infrared data at high spatial and temporal resolution, J. Hydrometeorol., 5, 487-503, doi:10.1175/1525-7541(2004)005<0487: CAMTPG $>2.0 . \mathrm{CO} ; 2$.

Lamptey, B. L. (2008), Comparison of gridded multisatellite rainfall estimates with gridded gauge rainfall over West Africa, J. Appl. Meteorol. Climatol., 40, 1801-1820.

Laurent, H., I. Jobard, and A. Toma (1998), Validation of satellite and ground-based estimates of precipitation over the Sahel, Atmos. Res., 47-48, 651-670, doi:10.1016/S0169-8095(98)00051-9.

Le Barbé, L., T. Lebel, and D. Tapsoba (2002), Rainfall variability in West Africa during the years 1950-90, J. Clim., 15, 187-202, doi:10.1175/ 1520-0442(2002)015<0187:RVIWAD $>2.0$.CO;2.

Le Houérou, H. N. (1989), The grazing land ecosystems of the African Sahel, Ecol. Stud., 75, 1-282.

Lebel, T., and A. Ali (2009), Recent trends in the Central and Western Sahel rainfall regime (1990-2007), J. Hydrol., 375(1-2), 52-64, doi:10.1016/j. jhydrol.2008.11.030.

Lebel, T., and A. Amani (1999), Rainfall estimation in the Sahel: What is the ground truth?, J. Appl. Meteorol., 38, 555-568, doi:10.1175/15200450(1999)038<0555:REITSW $>2.0$.CO;2.

Lebel, T., and L. Le Barbé (1997), Rainfall monitoring during HAPEXSahel: 2. Point and areal estimation at the event and seasonal scales, J. Hydrol., 188-189, 97-122, doi:10.1016/S0022-1694(96)03325-2.

Lebel, T., A. Diedhiou, and H. Laurent (2003), Seasonal cycle and interannual variability of the Sahelian rainfall at hydrological scales, J. Geophys. Res., 108(D8), 8389, doi:10.1029/2001JD001580.

Lo Seen, D., E. Mougin, S. Rambal, A. Gaston, and P. Hiernaux (1995), A regional Sahelian grassland model to be coupled with multispectral satellite data. II: Toward the control of its simulations by remotely sensed indices, Remote Sens. Environ., 52, 194-206, doi:10.1016/0034-4257(94)00127-9.

MacKinnon, D. J., G. D. Clow, R. K. Tigges, R. L. Reynolds, and P. S. Chavez Jr. (2004), Comparison of aerodynamically and model-derived roughness lengths $\left(\mathrm{z}_{0}\right)$ over diverse surfaces, central Mojave desert, California, USA, Geomorphology, 63, 103-113, doi:10.1016/j.geomorph. 2004.03.009.

Mangiarotti, S., P. Mazzega, L. Jarlan, E. Mougin, F. Baup, and J. Demarty (2008), Evolutionary bi-objective optimization of a semi-arid vegetation dynamics model with NDVI and $\sigma_{0}$ satellite data, Remote Sens. Environ., 112, 1365-1380, doi:10.1016/j.rse.2007.03.030.

Mathon, V., H. Laurent, and T. Lebel (2002), Mesoscale convective system rainfall in the Sahel, J. Appl. Meteorol., 41, 1081-1092, doi:10.1175/ 1520-0450(2002)041<1081:MCSRIT>2.0.CO;2.

Mougin, E., D. Lo Seen, S. Rambal, A. Gaston, and P. Hiernaux (1995), A regional Sahelian grassland model to be coupled with multispectral satellite data. I: Model description and validation, Remote Sens. Environ., 52, 181-193, doi:10.1016/0034-4257(94)00126-8.
Mougin, E., et al. (2009a), The AMMA-CATCH Gourma observatory site in Mali: Relating climatic variations to changes in vegetation, surface hydrology, fluxes and natural resources, J. Hydrol., 375, 14-33, doi:10.1016/j.jhydrol.2009.06.045.

Mougin, E., V. Demarez, M. Grippa, P. Hiernaux, L. Larouzière, C. Lion, M. Diawara, and N. Soumaguel (2009b), Evaluation of MODIS LAI products in a Sahelian environment (Gourma, Mali), paper presented at the 4th Global Vegetation Workshop, Univ. of Mont., Missoula, 16-19 June.

Mulitza, S., et al. (2010), Increase in African dust flux at the onset of commercial agriculture in the Sahel region, Nature, 466, 226-228, doi:10.1038/nature09213.

Myneni, R. B., et al. (2002), Global products of vegetation leaf area and fraction absorbed PAR from year one of MODIS data, Remote Sens. Environ., 83, 214-231, doi:10.1016/S0034-4257(02)00074-3.

Negri, A. J., E. J. Nelkin, R. F. Adler, G. J. Huffman, and C. Kummerow (1995), Evaluation of passive microwave precipitation algorithms in wintertime midlatitude situations, J. Atmos. Oceanic Technol., 12, 20-32, doi:10.1175/1520-0426(1995)012<0020:EOPMPA>2.0.CO;2.

Nicholson, S. E., et al. (2003), Validation of TRMM and other rainfall estimates with a high-density gauge dataset for West Africa. Part II: Validation of TRMM rainfall products, J. Appl. Meteorol., 42, 1355-1368, doi:10.1175/1520-0450(2003)042<1355:VOTAOR >2.0.CO;2.

Pan, M., H. Li, and E. Wood (2010), Assessing the skill of satellite-based precipitation estimates in hydrologic application, Water Resour. Res., 46 , W09535, doi:10.1029/2009WR008290

Rambal, S., and A. Cornet (1982), Simulation de l'utilisation de l'eau et de la production végétale d'une phytocénose sahélienne du Sénégal, Acta Oecologica Oecol. Plant, 4, 381-397.

Ramier, D., N. Boulain, B. Cappelaere, F. Timouk, M. Rabanit, C. R. Lloyd, S. Boubkraoui, F. Métayer, L. Descroix, and V. Wawrzyniak (2009), Towards an understanding of coupled physical and biological processes in the cultivated Sahel. 1: Energy and water, J. Hydrol., 375, 204-216, doi:10.1016/j.jhydrol.2008.12.002.

Roca, R., P. Chambon, I. Jobard, P.-E. Kirstetter, M. Gosset, and J.-C. Berges (2010), Comparing satellite and surface rainfall products over West Africa at meteorological relevant scales during the AMMA campaign using error estimates, J. Appl. Meteorol. Climatol., 49, 715-731, doi:10.1175/2009JAMC2318.1.

Sapiano, M. R. P., and P. A. Arkin (2009), An intercomparison and validation of high-resolution satellite precipitation estimates with 3-hourly gauge data, J. Hydrometeorol., 10, 149-166, doi:10.1175/2008JHM1052.1.

Sivakumar, M. V. K. (1992), Empirical analysis of dry spells for agricultural applications in West Africa, J. Clim., 5, 532-539, doi:10.1175/ 1520-0442(1992)005<0532:EAODSF $>2.0 . \mathrm{CO} ; 2$.

Sorooshian, S., K.-L. Hsu, X. Gao, H. V. Gupta, B. Imam, and D. Braithwaite (2000), Evaluation of PERSIANN system satellite-based estimates of tropical rainfall, Bull. Am. Meteorol. Soc., 81, 2035-2046, doi:10.1175/1520-0477(2000)081<2035:EOPSSE>2.3.CO;2.

Tracol, Y., E. Mougin, P. Hiernaux, and L. Jarlan (2006), Testing a Sahelian grassland functioning model against herbage mass measurements, Ecol. Modell., 193, 437-446, doi:10.1016/j.ecolmodel.2005.08.033.

Ushio, T., et al. (2006), A combined microwave and infrared radiometer approach for a high resolution global precipitation mapping in the GSMAP project Japan, paper presented at the 3rd International Precipitation Working Group Workshop on Precipitation Measurements, Int. Precip. Work. Group, Melbourne, Australia.

Xie, P., and P. A. Arkin (1996), Analysis of global monthly precipitation using gauge observations, satellite estimates, and numerical model prediction, J. Clim., 9, 840-858, doi:10.1175/1520-0442(1996)009<0840: AOGMPU $>2.0 . \mathrm{CO} ; 2$.

Yong, B., L.-L. Ren, Y. Hong, J.-H. Wang, J. J. Gourley, S.-H. Jiang, X. Chen, and W. Wang (2010), Hydrologic evaluation of Multisatellite Precipitation Analysis standard precipitation products in basins beyond its inclined latitude band: A case study in Laohahe basin, China, Water Resour. Res., 46, W07542, doi:10.1029/2009WR008965.

A. Ali, Centre Régional de Formation et d'Application en Agrométéorologie, Hydrologie et Météorologie, BP 11011, Niamey, Niger. G. Bergametti, B. Marticorena, and C. Pierre, Laboratoire Interuniversitaire des Systèmes Atmosphériques, Universités Paris-Est Créteil and Paris-Diderot, UMR CNRS 7583, 61 Av. du General de Gaulle, F-94010 Creteil CEDEX, France. (caroline.pierre@lisa.u-pec.fr)

T. Lebel, Laboratoire d'Etude des Transferts en Hydrologie et Environnement, UMR 5564 (CNRS-UJF-IRD-INPG), BP 53, F-38041 Grenoble CEDEX 9, France.

E. Mougin, Géosciences Environnement Toulouse, UMR 5563 (CNRS-IRD-UPS), Observatoire Midi-Pyrénées, 14 Av. Edouard Belin, F-31400 Toulouse, France. 